\title{
DENITRATION OF NITRIC ACID SOLUTIONS \\ BY FORMIC ACID
}

by

R. F. Bradley

C. B. Goodlett

$$
\text { Approved by }
$$

A. S. Jennings, Research Manager Separations Engineering Division

June 1972

\section{NOTICE}

This report was prepared as an account of work sponsored by the United States Government. Neither the United States nor the United States Atomic Energy Commission, nor any of their employees, nor any of Commission, nor any of thact ers, or their employees, their contractors, subcontractors, or their employees, makes any warranty, express or implied, or assucy, com. legal liability or responsibility for the accuraction, apparatus, pleteness or usefulness of any informe product or process disclosed, or represents

E. 1. DU PONT DE NEMOURS \& COMPANY SAVANNAH RIVER LABORATORY

AIKEN, S. C. 29801

CONTRACT AT(07-2).1 WITH THE

UNITED STATES ATOMIC ENERGY COMMISSION

This document is

PUBLICLY RELEASABRE

Rangsterle

Authorizing Official

Date: $\quad .4 / 36 / 06$

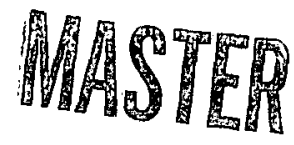




\section{DISCLAIMER}

This report was prepared as an account of work sponsored by an agency of the United States Government. Neither the United States Government nor any agency Thereof, nor any of their employees, makes any warranty, express or implied, or assumes any legal liability or responsibility for the accuracy, completeness, or usefulness of any information, apparatus, product, or process disclosed, or represents that its use would not infringe privately owned rights. Reference herein to any specific commercial product, process, or service by trade name, trademark, manufacturer, or otherwise does not necessarily constitute or imply its endorsement, recommendation, or favoring by the United States Government or any agency thereof. The views and opinions of authors expressed herein do not necessarily state or reflect those of the United States Government or any agency thereof. 


\section{DISCLAIMER}

Portions of this document may be illegible in electronic image products. Images are produced from the best available original document. 


\section{ABSTRACT}

A process was developed to reduce the nitric acid concentration of ion exchange feed solutions to $<1 \mathrm{M}$ by metering in formic acid to react with the nitric acid and form gases and water. Pressure surges are eliminated by allowing only a small amount of formic acid to accumulate in the system before the reaction initiates. The nitric acid solution is heated to $>90^{\circ} \mathrm{C}$ before formic acid addition begins, and the reaction is carried out under reflux. Laboratory tests were made to define the operating conditions of the denitration reaction and to develop mathematical models of the reaction behavior. Full-scale tests were then carried out with $10-\ell$ batches of nitric acid in prototype equipment to demonstrate that the reaction could be carried out accurately and safely and to define the operating characteristics of the equipment. 
CONTENTS

$\underline{\text { Page }}$

Introduction . . . . . . . . . . . . . . . . 7

Summary. . . . . . . . . . . . . . . . . 9

Discussion . . . . . . . . . . . . . . . 11

Alternative Methods of Denitration. . . . . . . . . 11

Previous Studies. . . . . . . . . . . . . 13

Denitration Equipment . . . . . . . . . . . . 14

Equipment. . . . . . . . . . . . . . . . . 14

Process Control. .................. 15

Laboratory Studies. . . . . . . . . . . . . 15

Equipment. . . . . . . . . . . . . . . . 16

Formic Acid Consumption. . . . . . . . . . . 16

Batch Denitrations . . . . . . . . . . . 20

Induction Time. . . . . . . . . . . . . . . 20

Maximum Gas Evolution Rates . . . . . . . . 22

Foam Height Studies. . . . . . . . . . . . 23

Semibatch Denitrations .. . . . . . . . . . 25

Induction Time. . . . . . . . . . . . . . . 25

Maximum Gas Evolution Rates........... . 25

Mixing Effects................ 28

Plant-Scale Studies . . . . . . . . . . . . . 30

Equipment. . . . . . ........... 30

Batch Denitrations............. . . 30

Semibatch Denitrations . . . . . . . . . . 37

Typical Plant Tests... . . . . . . . 37

Effect of Air Purge . . . . . . . . . . . . 38

Formic Acid Addition Rate... . . . . . . . 40

Maximum Gas Evolution Rates ..... . . . . . 43

Effect of Air Sparge. . . . . . . . . . . . 43

Corrosion .. . . . . . . . . . . . . . 44

References . . . . . . . . . . . . . . . . . 45 


\section{LIST OF FIGURES}

Figure

Page

1 Nitric Acid Removal by Water Stripping . . . . . . 11

2 Denitration System . . . . . . . . . . . . 14

3 Laboratory Denitration Apparatus . . . . . . . . 16

4 Autocatalytic Reactions . . . . . . . . . . . 17

5 Decrease in Reaction Rate at $<1 \mathrm{M}\left[\mathrm{H}^{+}\right]$

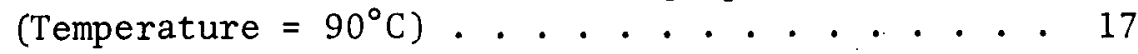

6 Optimum Amount of Formic Acid to be Added . . . . 18

7 Optimum Addition Ratio . . . . . . . . . . . . 19

8 Autothermal Behavior in Batch Denitration of

$8 \mathrm{M} \mathrm{HNO}_{3}$.................. 21

9 Induction Time in Batch Reactions . . . . . . . . 21

10 Maximum Gas Evolution Rates in Batch Reaction

(1.5 moles formic acid/mole nitric acid) . . . . . 23

11 Foam Formation in Cylindrical Vessels with

$8 \mathrm{M} \mathrm{HNO}_{3}$. . . . . . . . . . . . . . . . 24

12 Semibatch Denitration at $90^{\circ} \mathrm{C}$ and $2.5 \mathrm{cc}$ Formic

Acid per Minute per Liter of Feed . . . . . . . . 25

13 Induction Time in Semibatch Reactions . . . . . . . 27

14 Maximum Gas Evolution Rates in Semibatch Reactions . 28

15 Effect of Air Sparge on Semibatch Induction Time . . 29

16 Plant-Scale Denitration Evaporator Pot . . . . . . 31

17 Plant-Scale Denitration Condenser . . . . . . . 32

18 Plant-Scale Denitration Equipment . . . . . . . 33

19 Effect of Initial $\mathrm{HNO}_{3}$ Concentration on Peak Pressure Rise in Plant-Scale Batch Reactions . . . 34

20 Estimated Peak Off-Gas Evolution Rate in

Plant-Scale Batch Reactions . . . . . . . . . 35

21 Effect of Volume of Formic Acid Added on Peak

Pressure Rise in Plant-Scale Evaporator . . . . . 36

22 Plant-Scale Denitration with Formic Acid . . . . 37 
Figure

Page

23 Optimum Formic Acid/Nitric Acid Addition Ratio . . . 38

24 Effect of Formic Acid Feed Rate on Peak Pressure

Rises and Induction Time in Plant-Scale

Evaporator . . . . . . . . . . . . . 41

25 Semibatch Induction Times in Plant-Scale Tests . . . 42

26 Peak Off-Gas Rate .. . . . . . . . . . . . 43

27 Plant-Scale Evaporator at Conclusion of Tests. . . 44

\section{LIST OF TABLES}

Table

Page

I Denitration of $4 \mathrm{M} \mathrm{HNO}_{3}$ at $90^{\circ} \mathrm{C}$. . . . . . . . . 19

II Maximum Gas Evaluation Rates in Laboratory-Scale Batch Reactions . . . . . . . . . . . 22

III Effect of Air Purge Rate and Condenser Temperature on Formic Acid/Nitric Acid Ratio . . . . . . . . . 39 


\section{INTRODUCTION}

A new multipurpose processing facility is being installed at the Savannah River Plant to separate and purify transplutonium elements such as californium, einsteinium, fermium, curium, and americium. 'The transplutonium elements are separated from each other and from the lanthanide fission products by high pressure chromatographic ion exchange. ${ }^{1}$ The nitric acid concentration of the feed to the ion exchange columns must be reduced from $28 \mathrm{M}$ to $1 \mathrm{M}$ in order to load a maximum quantity of feed onto the column without premature breakthrough. A neutralizing agent such as $\mathrm{NaOH}$ cannot be used because it would add cations to the system.

A process has been developed at the Savannah River Laboratory to reduce the nitric acid concentration of solutions in an evaporator to $<1 \mathrm{M}$ by metering in formic acid. The formic acid reacts with the nitric acid to form gases ( $\mathrm{NO}, \mathrm{NO}_{2}, \mathrm{CO}_{2}$ ) and water. No cations are added to the system, none of the products of the reaction are solids, and no explosive nitrate compounds can be formed. The reaction is carried out rapidly and efficiently; the formic acid added as a $90 \%$ solution is not highly volatile. The volume of the system is almost unchanged by the denitration.

This report summarizes the laboratory and plant-scale studies that were made to determine the feasibility of this method for destroying nitric acid and to establish the conditions required to carry out this reaction safely and efficiently. The reaction is autocatalytic and autothermal and would give off large quantities of gas and heat if an excess of formic acid were allowed to accumulate in the system. 


\section{SUMMARY}

A process was developed to reduce the nitric acid concentration of ion exchange feed to < $1 \mathrm{M}$ by metering in fornic acid. The formic acid reacts with the nitric acid to form gases (NO, $\mathrm{NO}_{2}, \mathrm{CO}_{2}$ ) and water. Laboratory studies showed that the reaction was autocatalytic with an induction period. The energy of activation of the induction reaction was estimated to be $28 \mathrm{kcal} / \mathrm{g}$-mol. Laboratory studies were carried out to determine the following:

- Amount of formic acid to be added

- Induction period and maximum gas evolution rates for batch and semibatch reactions

- Foam formation

- Effect of mixing

Based on these laboratory tests, equations were derived to estimate the amount of formic acid accumulated in the system before initiation for semibatch denitrations (formic acid metered into the nitric acid) as a function of temperature, formic acid addition rate, and initial nitric acid concentration. These relationships were used to establish guidelines to ensure that the reaction would be carried out smoothly with a minimum quantity of formic acid accumulated in the system when the reaction initiates; a pot temperature $\geqslant 90^{\circ} \mathrm{C}$, and a formic acid addition rate of $\leqslant 0.06 \mathrm{~mol} / \mathrm{min}$ per liter of nitric acid.

The mixing studies showed that air sparging could significantly increase the induction period by removing the autocatalytic agents from the system.

Semiworks tests were carried out with full $10-\ell$ batches of $\mathrm{HNO}_{3}$ in a prototype evaporator. Batch reactions were carried out to determine the consequences of an accident in which all of the safety devices are bypassed and a stoichiometric mixture of formic acid and nitric acid are suddenly mixed and allowed to react. The peak pot pressure increased with acidity and solution temperature. When a stoichiometric quantity of formic acid was added to $8 \mathrm{M} \mathrm{HNO}_{3}$ at $90^{\circ} \mathrm{C}$, the peak pressure reached 60 inches of water after the reaction initiated. 
The semibatch denitrations were then carried out at design conditions (pot temperature $=90-95^{\circ} \mathrm{C}$, formic acid addition rate $=0.06 \mathrm{~mol} / \mathrm{min}$ per liter of $\mathrm{HNO}_{3}$ ) for feed up to $15.6 \mathrm{M} \mathrm{HNO}_{3}$. The final $\mathrm{HNO}_{3}$ concentration varied from 0.1 to $0.8 \mathrm{M}$. The peak pressure developed in the system did not exceed 1.3 inches of water. Initiation of the reaction was determined by a sudden increase in liquid temperature and a corresponding decrease in specific gravity. The decrease in specific gravity also was useful in following the course of the denitration reaction.

Additional plant-scale semibatch denitrations showed that formic acid addition rates up to 4 times the normal plant rate were acceptable at $\mathrm{HNO}_{3}$ concentrations $<8 \mathrm{M}$, that an air purge to the vapor space of $>0.3 \mathrm{scfm}$ could increase the formic acid consumption ratio above the stoichiometric minimum, and that air sparging of the liquid significantly increased the induction period.

Results of the laboratory and plant-scale studies were in good agreement.

Inspection of the prototype evaporator after all of the tests were completed showed corrosion to be negligible. 
DISCUSSION

ALTERNATIVE METHODS OF DENITRATION

Several alternative methods of denitration were investigated. Water stripping is effective at higher acidities; however, at concentrations less than about 4M stripping becomes relatively inefficient (Figure 1).

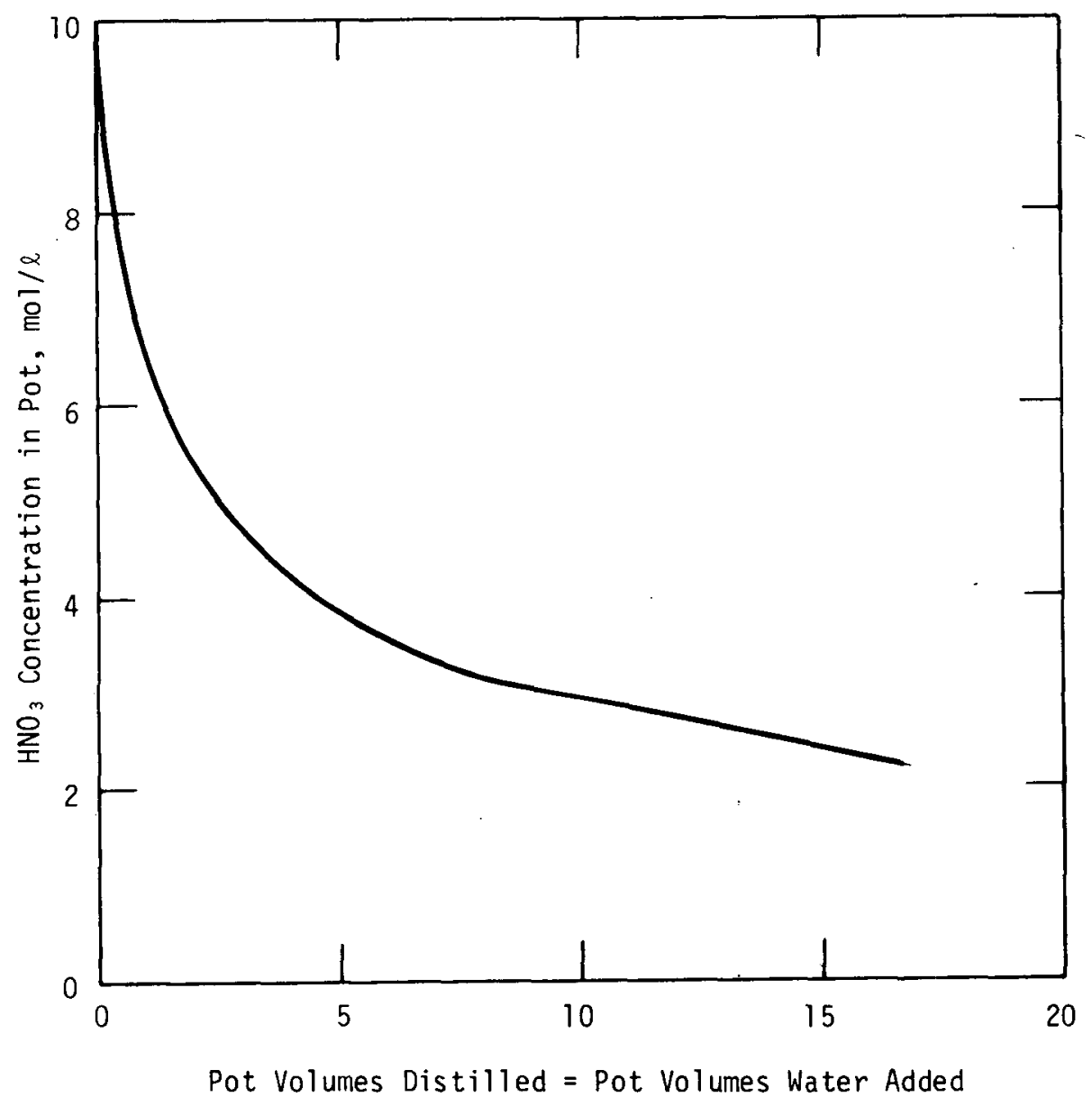

FIGURE I Nitric Acid Removal by Water Stripping 
Several organic compounds which have been used to destroy nitric acid in radioactive wastes, such as sugar, ${ }^{2}$ formaldehyde, ${ }^{3}$ and para-formaldehyde, ${ }^{4}$ were also studied. Reaction times were excessive when sugar was used, and precipitates formed. during the reaction from the degradation products of the sugar. When sugar is added as an aqueous solution ( $65 \mathrm{wt} \%$ sugar), it is necessary to boil off the added water. Formaldehyde has the disadvantage of high volatility which causes process control problems because the formaldehyde distills over to the condenser, where the reaction takes place. Formaldehyde must also be added as a $35 \mathrm{wt} \%$ solution in water. Para-formaldehyde is not volatile; however, it is only $20 \mathrm{wt} \%$ in an aqueous solution, requiring excessive boiling during the reaction.

Denitration with formic acid has the following advantages:

- No cations are added to the system.

- None of the products of the reaction are solids.

- No explosive nitrate compounds can be formed.

- Very little water is added as solvent.

- Formic acid is not highly volatile.

- The reaction rate is relatively fast.

The principal disadvantage of formic acid denitration is that a large amount of gas and heat are evolved rapidly if an excessive amount of formic acid accumulates in concentrated nitric acid and then reacts. Due to the high value of the transplutonium elements in the feed and their radiation hazard, process operating conditions were determined to ensure a uniform, mild rate of reaction during denitration. 
PREVIOUS STUDIES

The reaction of $\mathrm{HNO}_{3}$ with $\mathrm{HCOOH}$ has been investigated by Healy. ${ }^{5}$ At nitric acid concentrations of 1 to $\sim 4 \mathrm{M}$ the general reaction is:

$$
\mathrm{HNO}_{3}+3 / 2 \mathrm{HCOOH}=\mathrm{NO}+3 / 2 \mathrm{CO}_{2}+2 \mathrm{H}_{2} \mathrm{O}
$$

At higher nitric acid concentrations, some of the $\mathrm{NO}$ is converted to $\mathrm{NO}_{2}$ :

$$
\mathrm{NO}+2 \mathrm{HNO}_{3} \neq 3 \mathrm{NO}_{2}+\mathrm{H}_{2} \mathrm{O}
$$

At nitric acid concentrations of 14 to $16 \mathrm{M}$, all of the NO is converted and the general reaction becomes:

$$
\mathrm{HNO}_{3}+1 / 2 \mathrm{HCOOH}=\mathrm{NO}_{2}+1 / 2 \mathrm{CO}_{2}+\mathrm{H}_{2} \mathrm{O}
$$

The kinetics of the reaction were studies by Longstaff and Singer. ${ }^{6}$ The reaction rate was found to be first order with respect to nitrous acid $\left(\mathrm{HNO}_{2}\right)$ and formic acid. The concentration of nitrous acid increased autocatalytically in $>1 \mathrm{M}$ nitric acid solutions when formic acid was added. The rate-determining step was postulated to be a bimolecular reaction between formic acid and nitrous acid in $<2.5 \mathrm{M}$ nitric acid, and between formic acid and $\mathrm{NO}^{+}$at higher nitric acid concentrations. Healy ${ }^{5}$ found that the rate of reaction at $100^{\circ} \mathrm{C}$ for a nitric acid range of $2-12 \mathrm{M}$ was given by:

$$
-\frac{\mathrm{d}(\mathrm{HCOOH})}{\mathrm{dt}}=k[\mathrm{HCOOH}]^{\mathrm{n}}\left[\mathrm{HNO}_{3}\right]^{3}
$$

Formic acid has been used to remove excess nitric acid during the processing of 210 Po. ${ }^{7}$ The formic acid was added in small increments to a heated solution that was vigorously agitated by a stream of $\mathrm{N}_{2}$ introduced below the surface of the liquid. 


\section{DENITRATION EQUIPMENT}

\section{Equipment}

The denitration is carried out in a $150-l$ evaporator, which is used to prepare feed for ion exchange processing (Figure 2). The evaporator is equipped with a formic acid addition line, through which the formic acid is allowed to drop onto the surface of the liquid. The condenser is designed to allow refluxing during denitration, and there is a blow-out leg on the condenser to relieve the system at a pressure of 1 inch of water (at the blow-out leg) in the event of an excessive reaction rate.

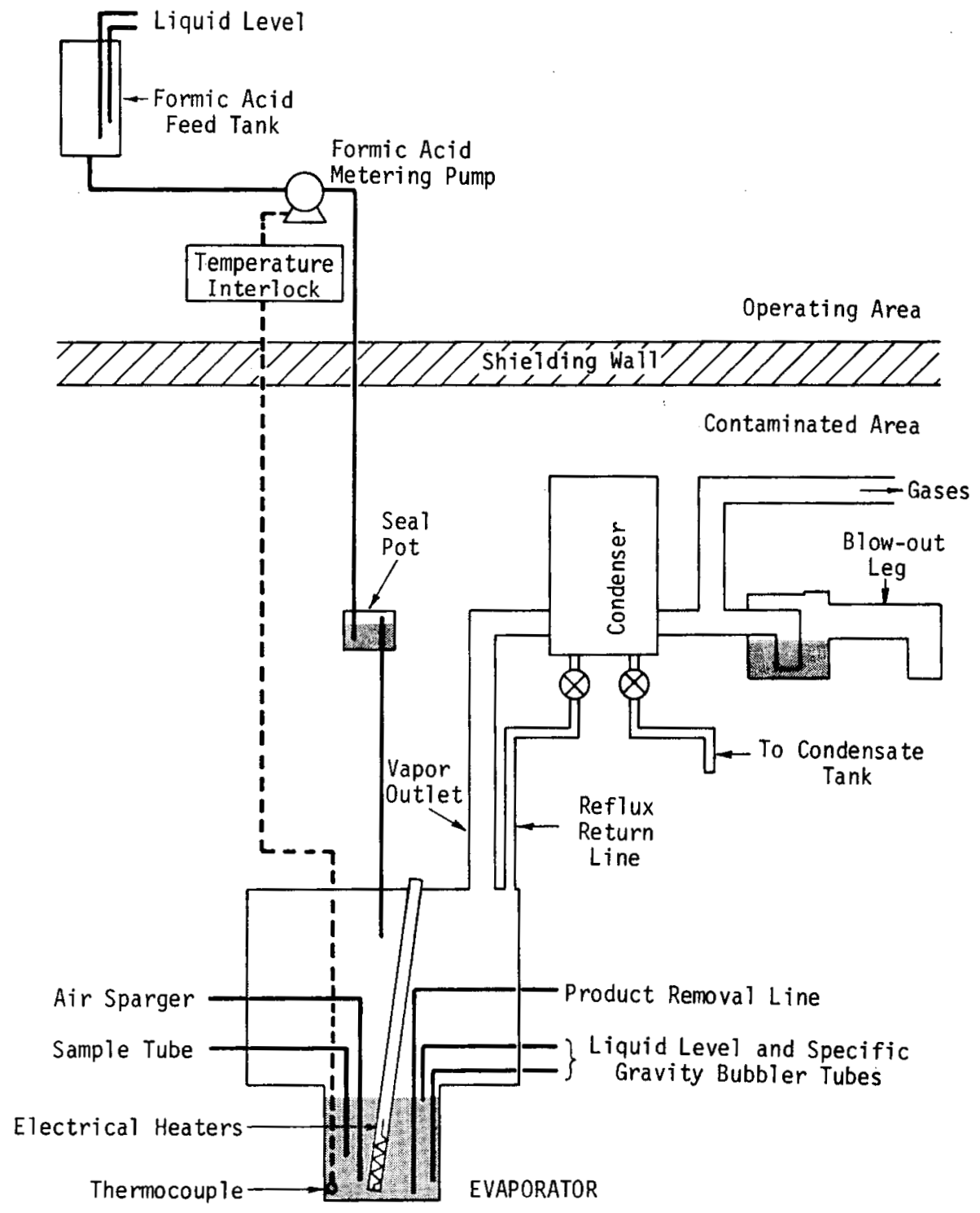

FIGURE 2 Denitration System 
The evaporator is also equipped with bubblers to measure liquid level and specific gravity, a sample line, a product removal line, a water addition line for stripping, and an air sparger to mix the contents of the vessel before sampling. Thermocouples measure the liquid temperature and the off-gas temperature. Cold feed is added through seal pots which maintain a liquid seal at pressures up to 98 inches of water in order to prevent vapors from passing up through the cold feed lines. The solution is boiled down to a final volume of $210 \ell$ in the evaporator and then denitrated.

\section{Process Control}

Procedural and engineered controls are used to prevent a thermal excursion. These controls ensure that the formic acid is added to a heated solution at a rate such that very little formic acid has accumulated in the system when the reaction initiates. The maximum rate of formic acid addition is set by the maximum capacity of the pumping system. A temperature interlock between the liquid temperature thermocouple, and the pump prevents the addition of formic acid to the system unless the liquid temperature is at least $90^{\circ} \mathrm{C}$. The acidity of the solution is measured before the run, and the proper total amount of formic acid is added to the formic acid feed tank. The initiation of the reaction is determined by an increase in the liquid temperature and a decrease in the specific gravity a few minutes after formic acid begins flowing into the pot. The rate of nitric acid removal is followed continuously by the change in specific gravity of the solution. After all of the formic acid has been added, the solution is refluxed one to two hours and then sampled.

\section{LABORATORY STUDIES}

Laboratory studies with $<1$ \& of acid were carried out to determine the following:

- Amount of formic acid to be added

- Induction period and maximum gas evolution rates for batch and semibatch reactions

- Foam formation

- Effect of mixing

Batch tests were run to study the kinetics of the system and to evaluate the consequences of suddenly adding large amounts of formic acid to the nitric acid. Semibatch tests were made under various conditions to determine the operating conditions of the process. 


\section{Equipment}

Argon was bubbled through the acid solution for $v_{1}$ hour before each run to remove any nitrous acid. Formic acid was added as a $90 \mathrm{wt} \%$ aqueous solution $(23.5 \mathrm{~mol} \mathrm{HCOOH} / \ell)$. The laboratory apparatus for a typical semibatch denitration is shown in Figure 3. Samples were taken continuously during the run and immediately analyzed for total acid by titration.

Small quantities of rare earths (0.1-0.2M) were added to the feed for some of the tests to simulate the presence of these cations in ion exchange feed solutions; however, at this concentration level there was no effect on the denitration reaction.

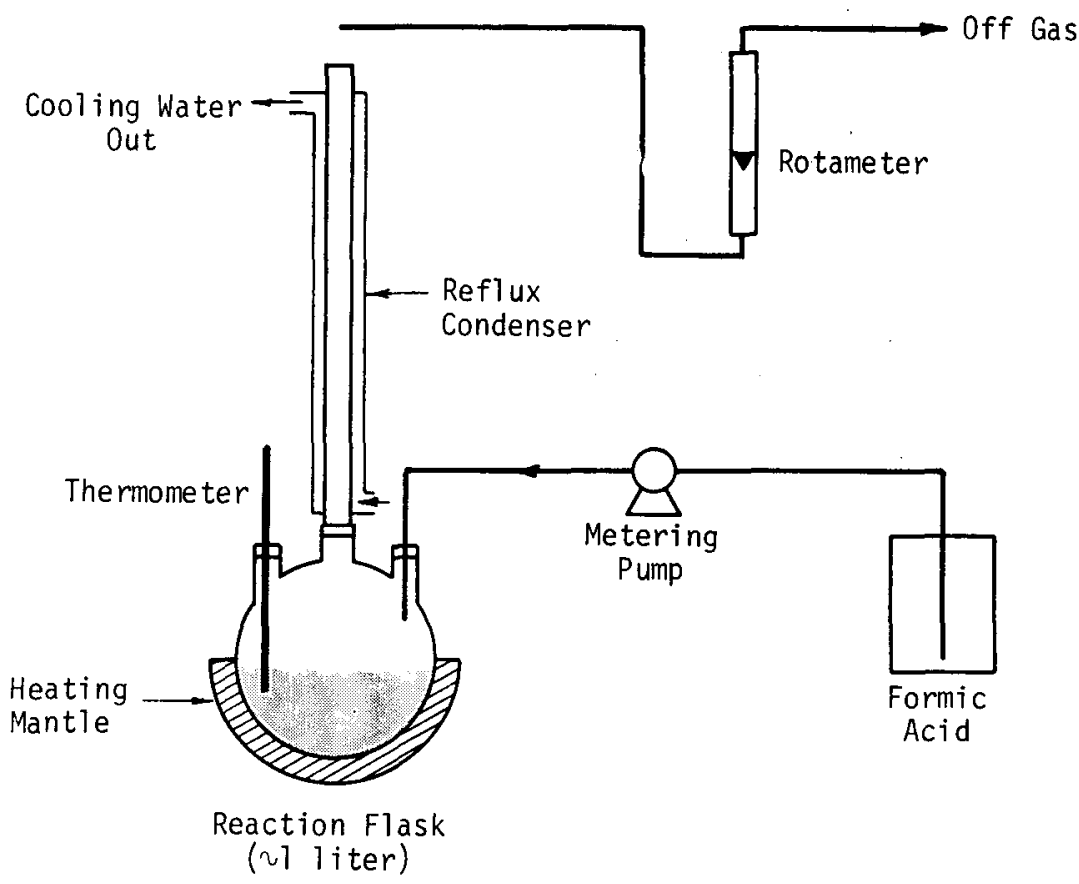

FIGURE 3 Laboratory Denitration Apparatus

\section{Formic Acid Consumption}

A series of batch reactions were carried out at various temperatures in a solution that was initially $3.3 \mathrm{M}$ in $\mathrm{HNO}_{3}$ and $3.9 \mathrm{M}$ in $\mathrm{HCOOH}$. The reaction is of an autocatalytic nature with an induction period that decreases rapidly with temperature (Figure 4). The reaction rate decreases rapidly at concentrations below $21 \mathrm{M}\left[\mathrm{H}^{+}\right]$(Figure 5). Reaction mixtures were refluxed at least 2 hours after all formic acid had been added to compensate for the slow reaction rate at the lower acidity. 


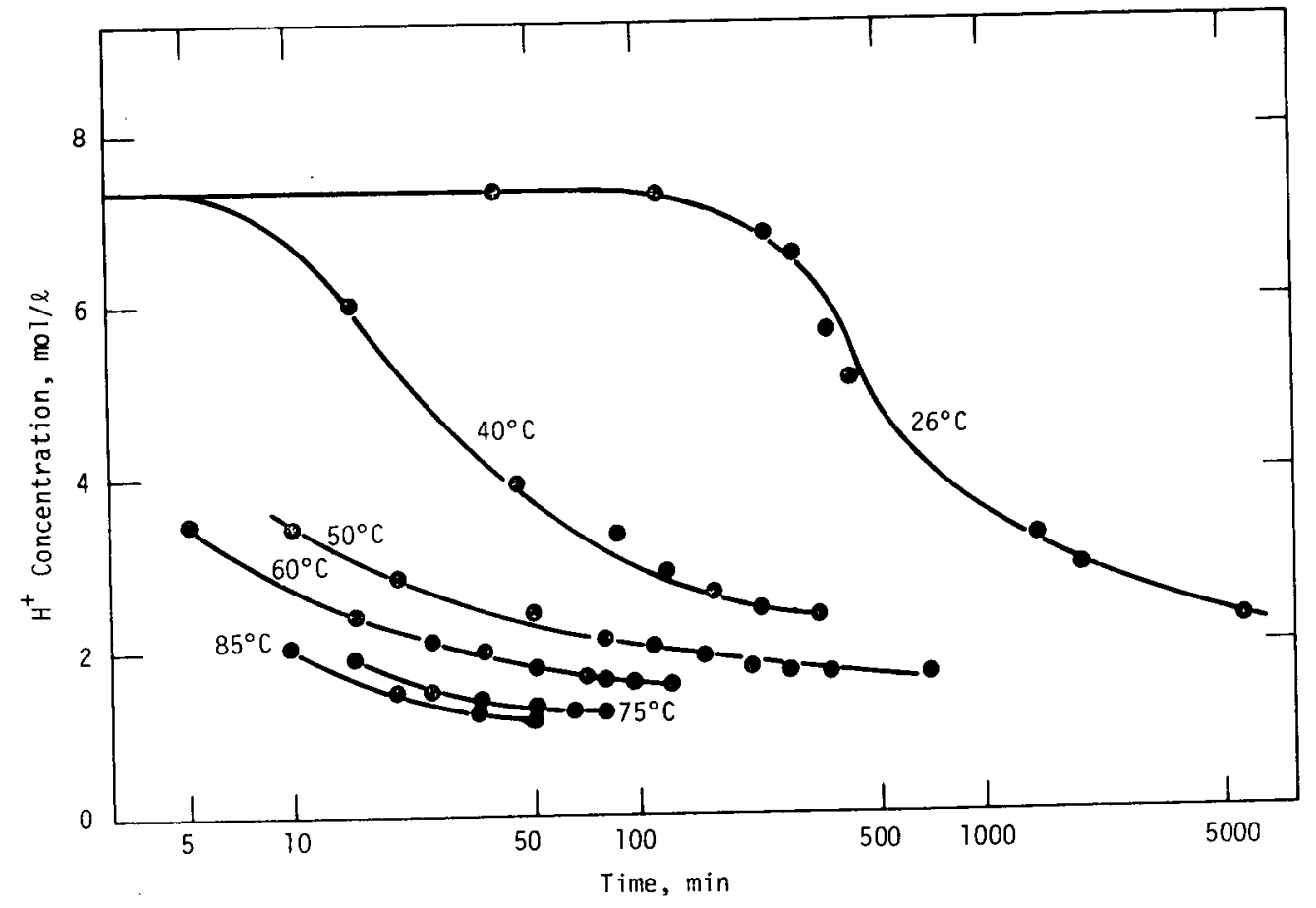

FIGURE 4 Autocatalytic Reactions

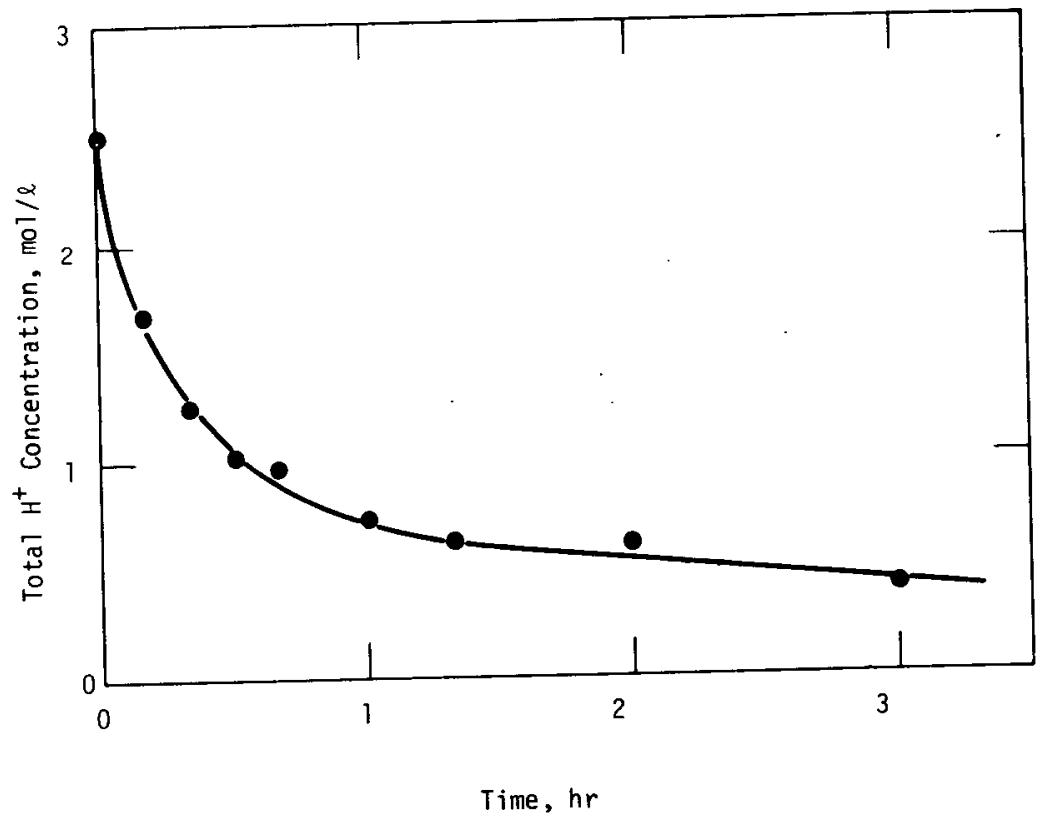

FIGURE 5 Decrease in Reaction Rate at $<1 M\left[\mathrm{H}^{+}\right]$ (Temperature $=90^{\circ} \mathrm{C}$ ) 
A series of tests were made in which varying amounts of formic acid were added slowly to nitric acid solutions, and the solution then heated for 3 hours at $90^{\circ} \mathrm{C}$ to determine the optimum amount of formic acid to be added in order to reduce the total acidity to <1M. This procedure was carried out for acidities up to $16 \mathrm{M}$ (Figure 6 ). The optimum reactant ratio for the $4 \mathrm{M} \mathrm{HNO}_{3}$ solution was also the theoretical stoichiometric ratio given by Equation 1 (Table I).

At higher acidities the reactant ratio must be determined experimentally because some of the $\mathrm{NO}$ is reacting with $\mathrm{HNO}_{3}$ as given by Equation 2. Figure 6 gives the optimum or stoichiometric amount of formic acid to be added. The upper addition limit defines the region in which the final acidity is $>1 M$ due to an

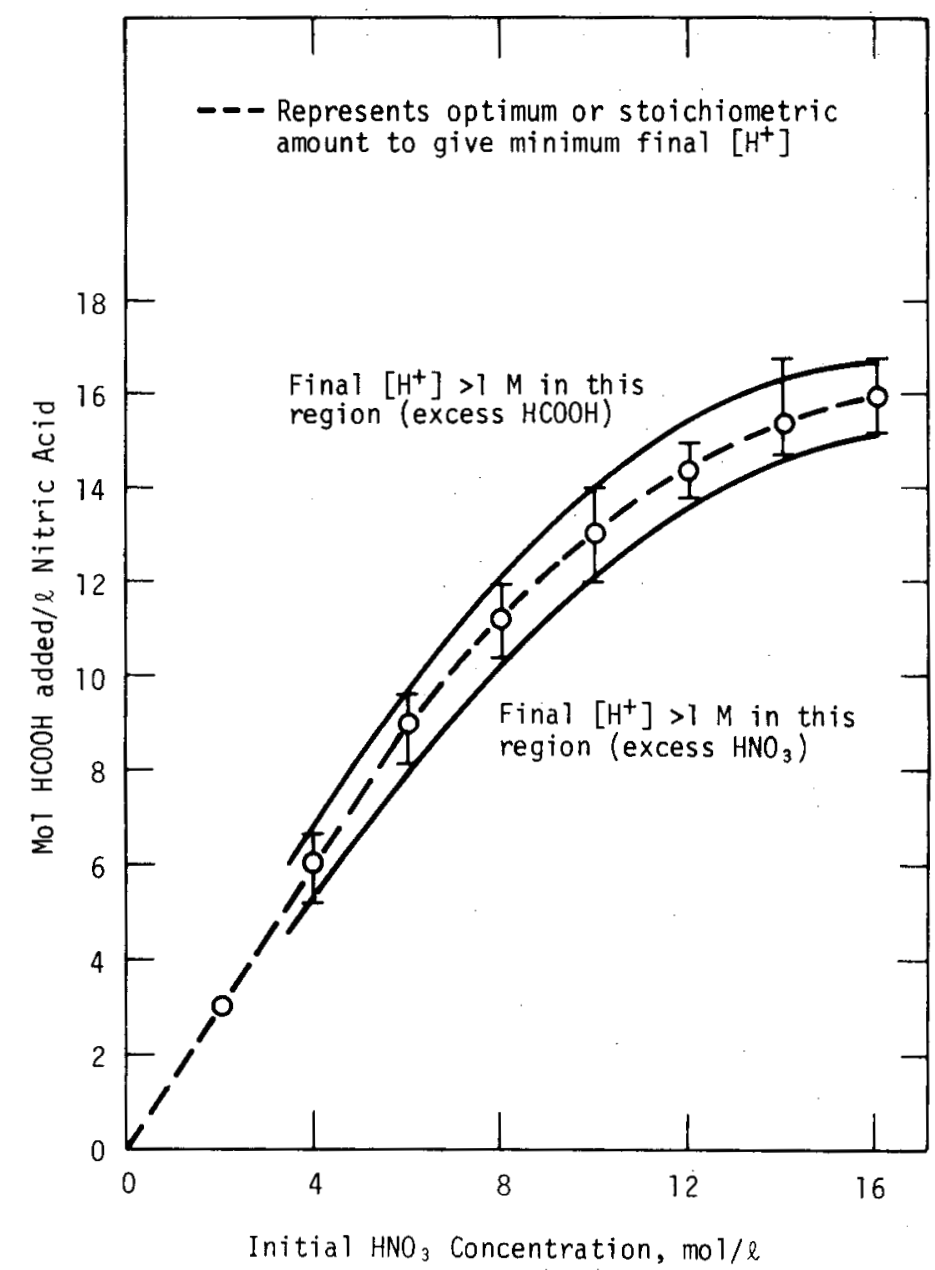

FIGURE 6 Optimum Amount of Formic Acid to be Added 
excess of formic acid. The lower addition limit defines the region in which the final acidity was $>1 M$ due to an excess of nitric acid.

The stoichiometric addition ratio based on these data is given in Figure 7.

Volume changes due to the denitration were found to be small $(<1 \%)$.

\section{TABLE I}

Denitration of $4 \mathrm{M} \mathrm{HNO}$ at $90^{\circ} \mathrm{C}$

$(\mathrm{Mol} \mathrm{HCOOH}) /\left(\mathrm{Mol} \mathrm{HNO}_{3}\right)$ Total $\mathrm{H}^{+}$after $3 \mathrm{hrs}$, mol $/ \ell$

0.95

1.75

1.3

1.5 (stoichiometric

0.95

ratio)

1.65

2.74

1.05

3.5

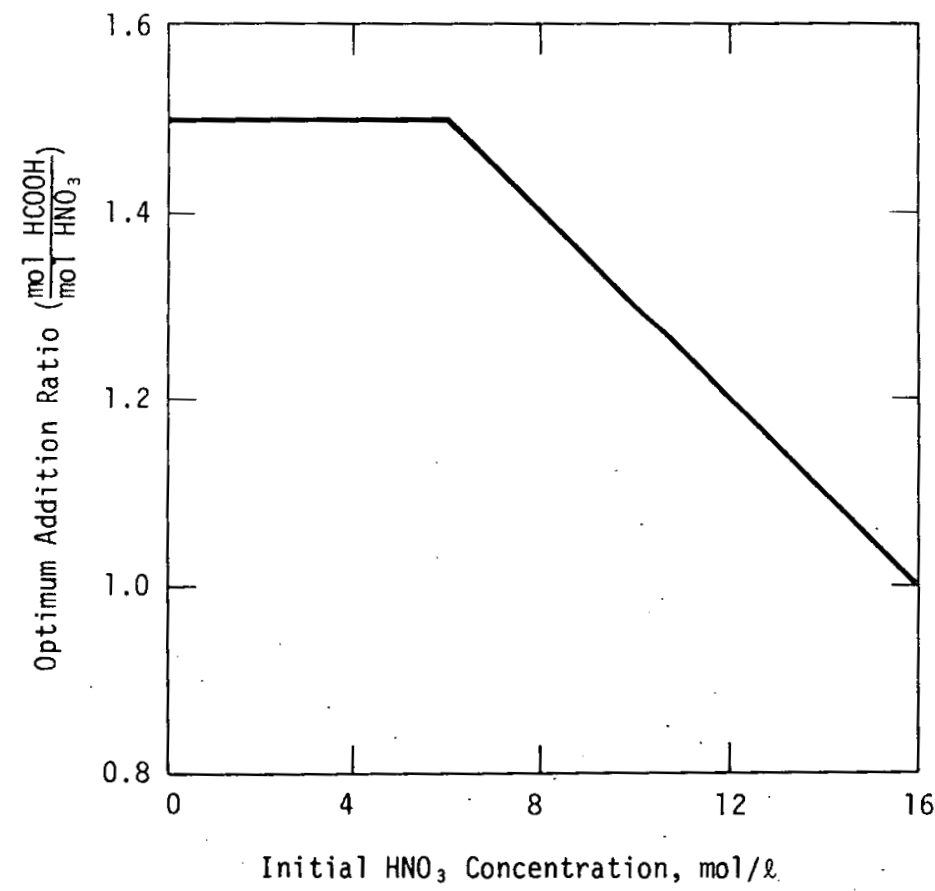

FIGURE 7 Optimum Addition Ratio 


\section{Batch Denitrations}

\section{Induction Time}

A study was made to determine the effect of temperature, nitric acid concentration, and formic acid concentration on the induction time in batch reactions. Due to the autocatalytic and autothermal nature of the reaction, the induction time was easily determined by the sudden increase in temperature at initiation (Figure 8 ). The data were correlated by plotting the reciprocal of the induction time vs the reciprocal of the absolute temperature (Figure 9). The induction time data are correlated by the following equation:

$$
\frac{1}{t^{*}}=2.4 \times 10^{17}\left[\mathrm{HNO}_{3}\right][\mathrm{HCOOH}] \exp \frac{-27,800}{\mathrm{RT}}
$$

where

$$
\begin{aligned}
\mathrm{t}^{*} & =\text { batch induction time, min } \\
{\left[\mathrm{HNO}_{2}\right][\mathrm{HCOOH}] } & =\text { concentrations, mol } / \ell \\
\mathrm{T} & =\text { absolute temperature, }{ }^{\circ} \mathrm{K} \\
\mathrm{R} & =1.98 \mathrm{cal} / \mathrm{g}-\mathrm{mo} 1-{ }^{\circ} \mathrm{K}
\end{aligned}
$$

This relationship suggests that during the induction period an autocatalytic agent is formed from the reaction of $\mathrm{HNO}_{3}$ and $\mathrm{HCOOH}$, the activation energy of the reaction being 27.8 cal/g-mol. The rate of formation of this autocatalytic agent $\left(\mathrm{HNO}_{2}, \mathrm{NO}^{+}\right.$or some species in equilibrium with these components) would be inversely proportional to the induction veriod:

$$
\frac{\mathrm{d}(\mathrm{I})}{\mathrm{dt}}=\mathrm{C} \frac{1}{\mathrm{t}^{*}}=\mathrm{K}_{1}\left[\mathrm{HNO}_{3}\right][\mathrm{HCOOH}] \exp \left(\frac{-27,800}{\mathrm{RT}}\right)
$$

where

(I) = concentration of autocatalytic agent

$\mathrm{C}, \mathrm{k}_{1}=$ constants

Equation 6 can be integrated to obtain the relationship between the critical concentration of autocatalytic agent necessary to initiate the reaction ( $I)^{*}$ and the batch induction time $t^{*}$ :

$$
(\mathrm{I})^{*}=\mathrm{k}_{1}\left[\mathrm{HNO}_{3}\right][\mathrm{HCOOH}] \exp \left(\frac{-27,800}{\mathrm{RT}}\right) t *
$$

These equations will be used subsequently to derive semibatch induction times. 


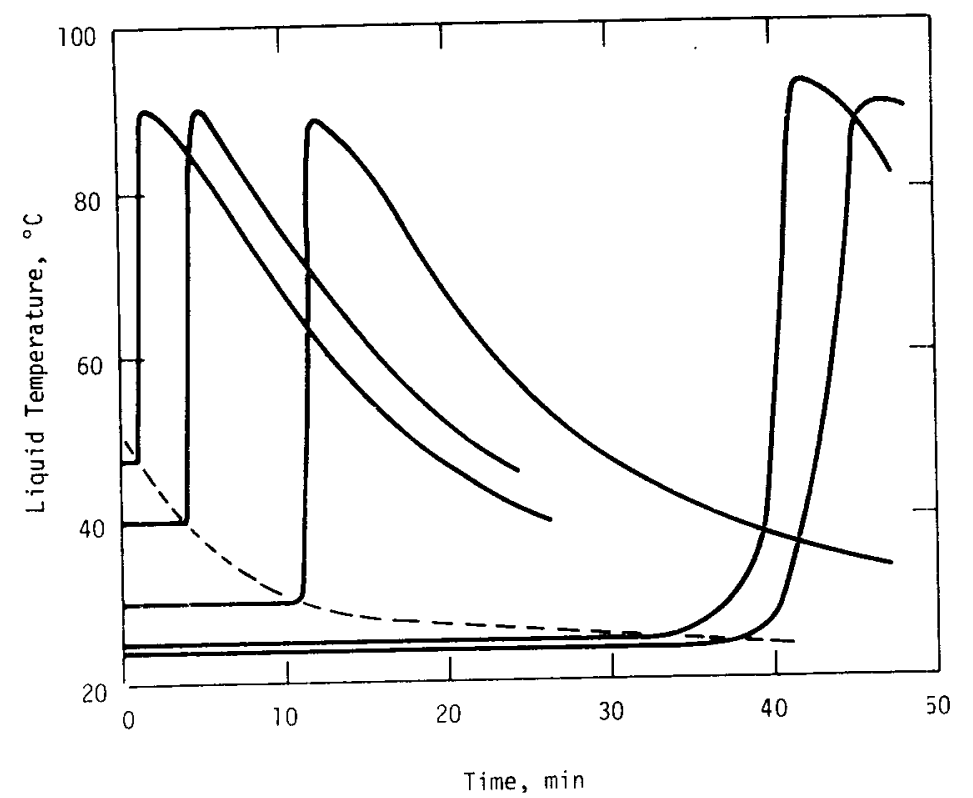

FIGURE 8 Autothermal Behavior in Batch Denitration of $8 \mathrm{M} \mathrm{HNO}_{3}$

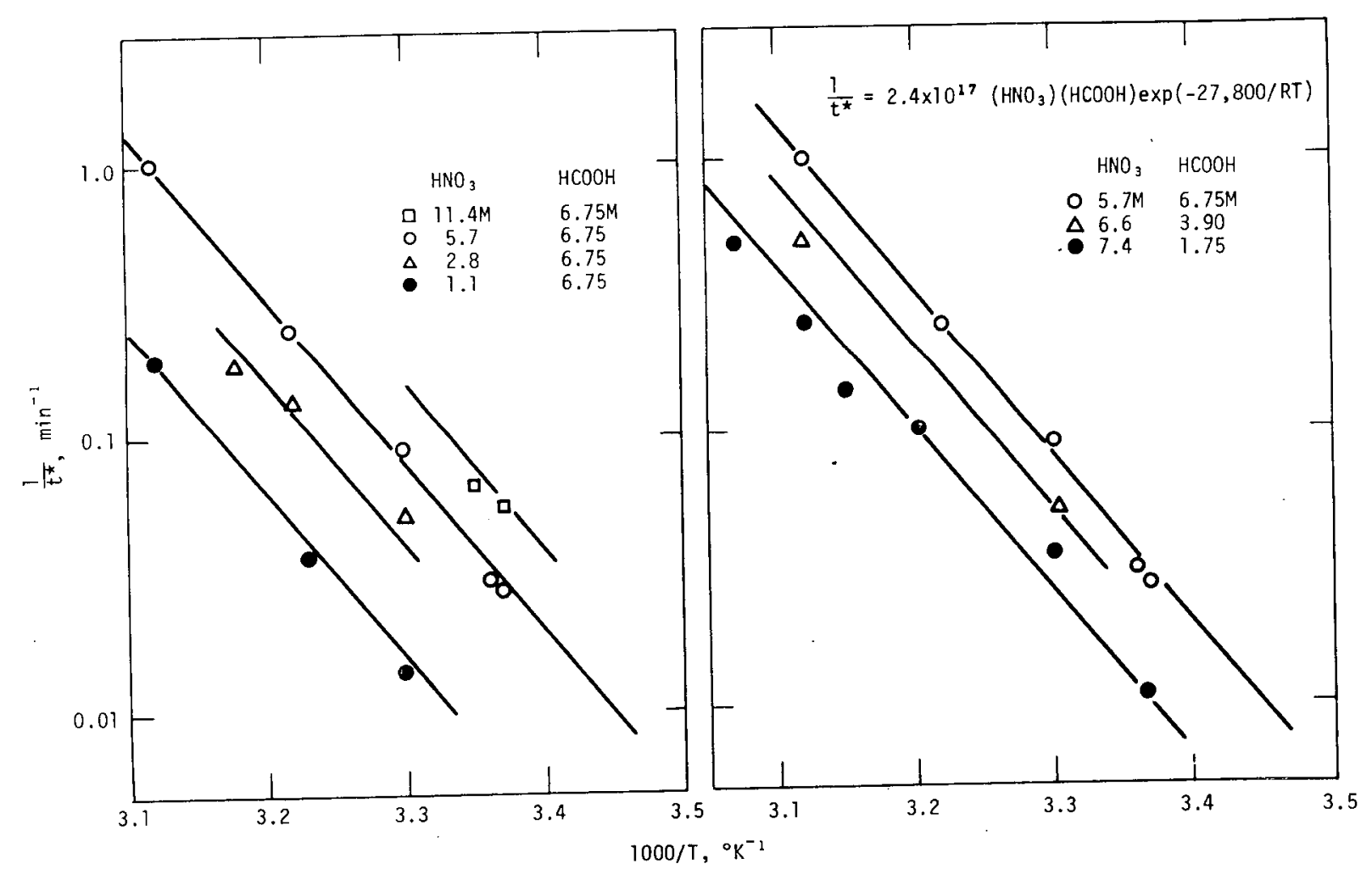

FIGURE 9 Induction Time in Batch Reactions 
Although the pump temperature interlock system prevents the sudden addition of large amounts of formic acid to the cold nitric acid, the maximum gas evolution rate should occur when excess quantities of formic acid are suddenly mixed with nitric acid. As soon as the reaction initiates, the gas rate increases as the concentration of the autocatalytic agent increases. The rate reaches a peak and then begins to decrease when a significant amount of the autocatalytic agent has been consumed by reaction. Peak gas evolution rates were determined experimentally for several ratios of formic acid to nitric acid in solutions of varying nitric acid concentration (Table II). The solution was initially at room temperature but heated rapidly to $290^{\circ} \mathrm{C}$ as soon as the reaction initiated.

\section{TABLE II}

\begin{tabular}{|c|c|c|}
\hline \multicolumn{3}{|c|}{$\begin{array}{l}\text { Maximum Gas Evolution Rates In } \\
\text { Laboratory-Scale Batch Reactions }\end{array}$} \\
\hline $\begin{array}{c}\text { Initial } \mathrm{HNO}_{3} \\
\text { Concentration, mo } 1 / \ell \\
\end{array}$ & $\frac{\text { mol formic }}{\text { mol nitric }}$ & $\begin{array}{l}\text { Maximum Gas Evolution } \\
\text { Rate, } \mathrm{cc} / \mathrm{sec}-\ell \\
\end{array}$ \\
\hline 0.5 & 1.5 & 1 \\
\hline 0.5 & 3.0 & 2 \\
\hline 0.5 & 4.5 & 9 \\
\hline 0.5 & 6.0 & 10 \\
\hline 1.0 & 1.5 & 18 \\
\hline 1.0 & 3.0 & 64 \\
\hline 1.0 & 4.5 & 104 \\
\hline 1.0 & 7.5 & 104 \\
\hline 1.0 & 9.0 & 104 \\
\hline 1.0 & 12.5 & 104 \\
\hline 2.0 & 1.5 & 360 \\
\hline 2.0 & 3.0 & 690 \\
\hline 2.0 & 4.5 & 1040 \\
\hline 3.0 & 1.5 & 900 \\
\hline 4.0 & 1.5 & 1400 \\
\hline 5.0 & 1.5 & 2500 \\
\hline
\end{tabular}

The maximum gas evolution rate increased as the amount of formic acid added increased. Based on the data for 0.5 and $1.0 \mathrm{M} \mathrm{HNO}_{3}$ solutions, the peak rates leveled off at ratios of $\checkmark 5$ moles formic acid per mole of nitric acid. In order to eliminate the possibility of adding an amount of formic acid several times in excess of the stoichiometric ratio, the formic acid feed tank should be sized for only the maximum amount of formic acid needed to carry out a single denitration. 
The maximum gas evolution rate for a stoichiometric mixture was approximately a square function of the nitric acid concentration in the range studied, up to $5 \mathrm{M} \mathrm{HNO} \mathrm{H}_{3}$ (Figure 10).

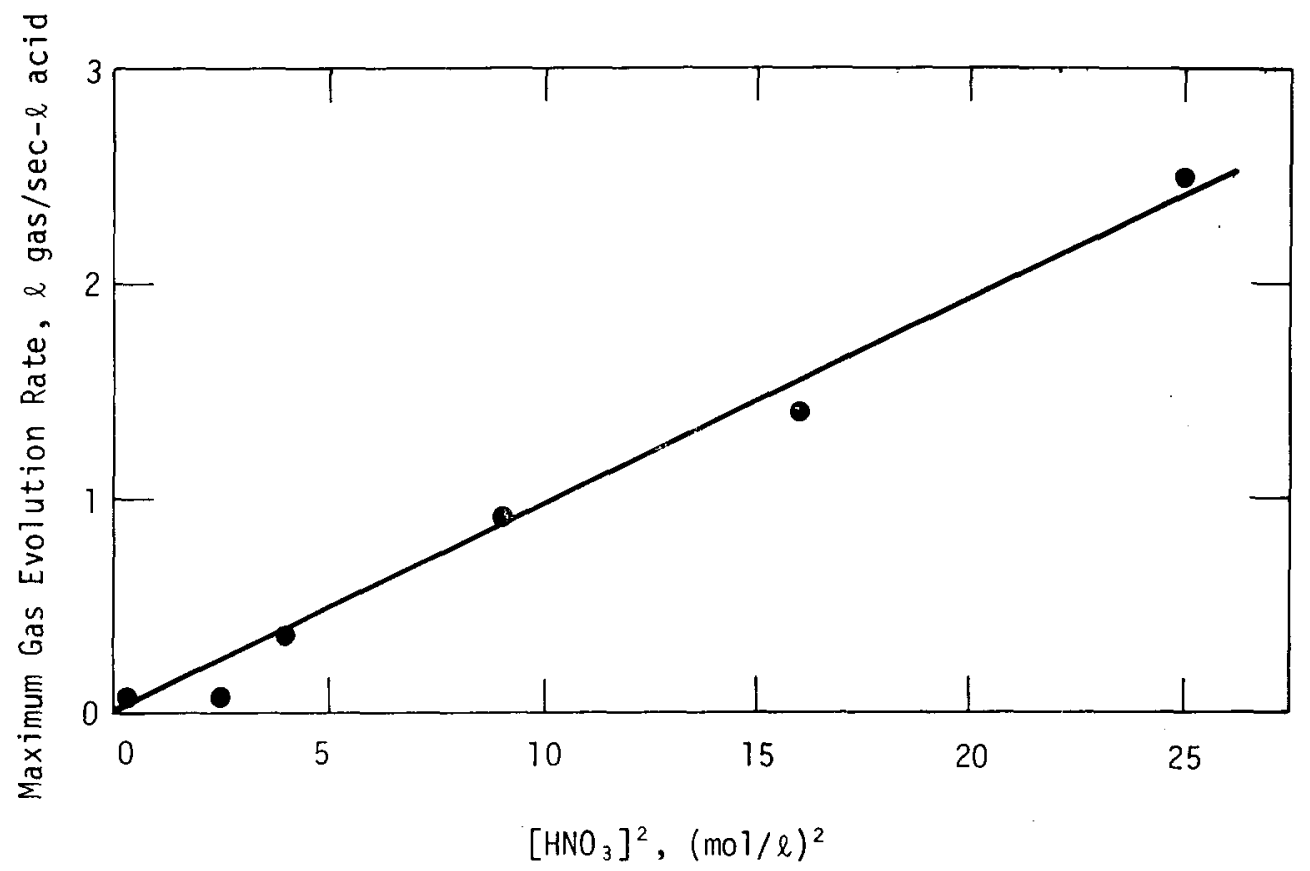

FIGURE 10 Maximum Gas Evolution Rates in Batch Reaction ( 1.5 moles formic acid/mole nitric acid)

Foam Height Studies

One of the principal problems of batch reactions, in addition to high gas evolution rates, is the foam and mist that result. In order to get a quantitative estimate of the peak foam heights that might occur, the reaction was initiated in an $8 \mathrm{M} \mathrm{HNO}_{3}$ solution to which varying amounts of formic acid had been added (Figure 11). Based on these data, if a stoichiometric quantity

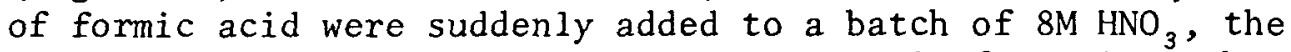
foam height would reach a level approximately four times the liquid height. However, this level would still be contained in the evaporator pot. Semibatch operation reduces peak foam heights to negligible values. 


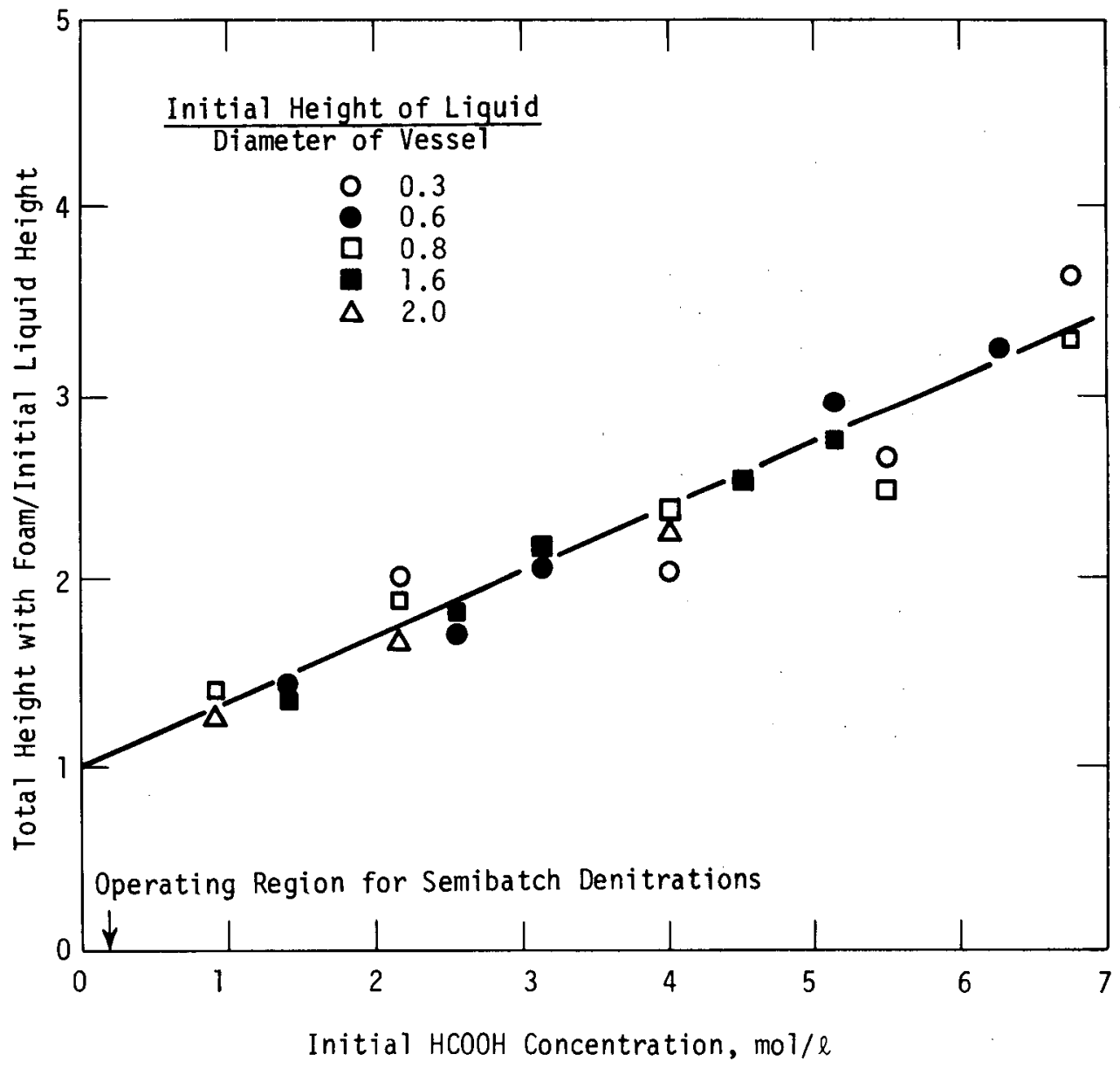

FIGURE 11 Foam Formation in Cylindrical Vessels with $8 \mathrm{M} \mathrm{HNO}_{3}$ 


\section{Semibatch Denitrations}

The laboratory-scale semibatch denitrations were carried out by metering a $90 \mathrm{wt} \%$ formic acid solution at $2.5 \mathrm{cc} / \mathrm{min}-\ell \mathrm{HNO}_{3}$ $\left(0.06 \mathrm{~mol} / \mathrm{min}-\ell \mathrm{HNO}_{3}\right)$ into nitric acid solutions which were at $90^{\circ} \mathrm{C}$. The total amount of formic acid added was determined from the stoichiometric ratios given in Figure 6 . Nitric acid solutions of varying initial concentration were reduced to $21 \mathrm{M}^{+}$by the semibatch method (Figure 12). Under these conditions, $8 \mathrm{M}$ feed could be denitrated in less than 4 hours.

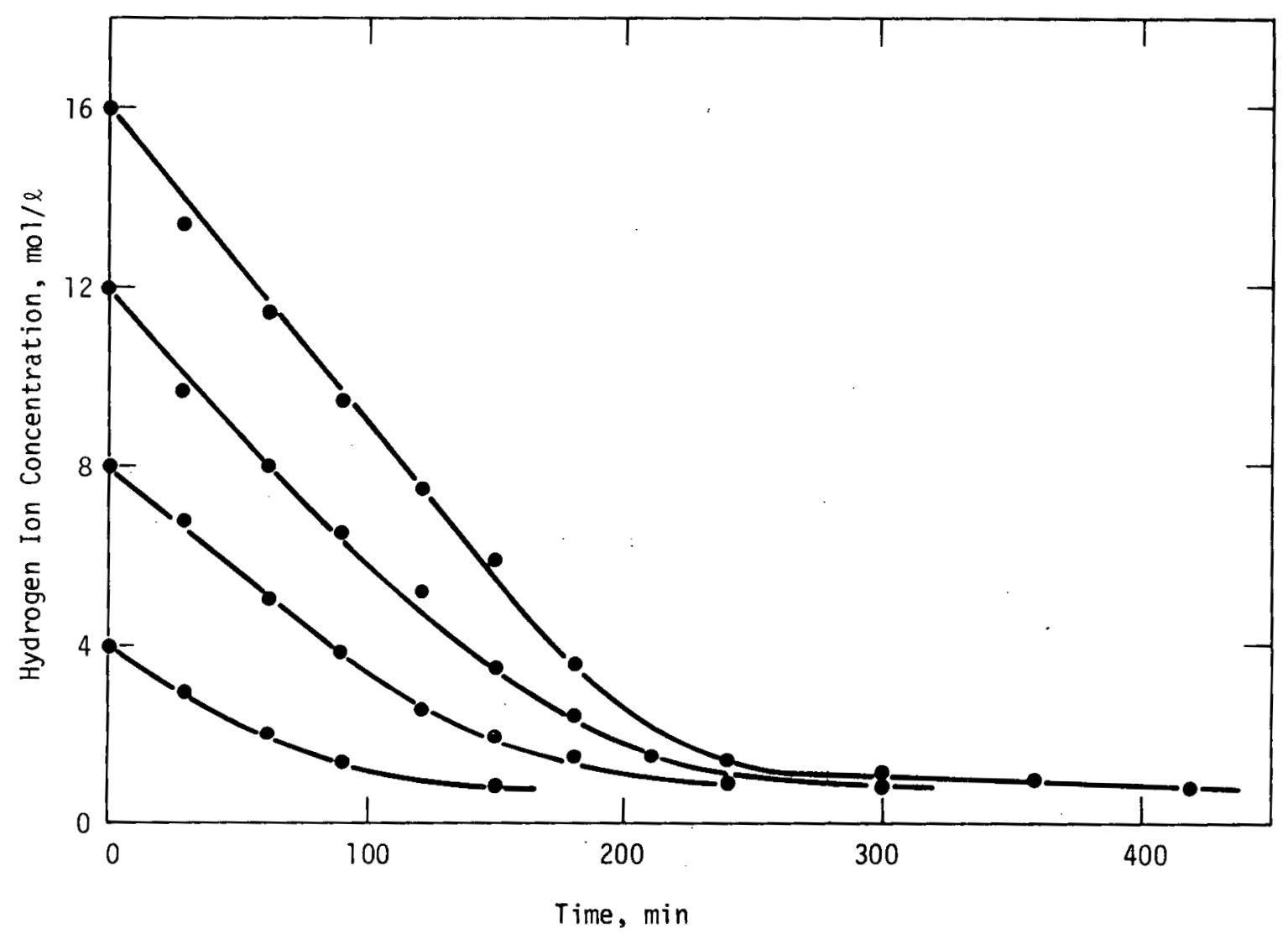

FIGURE 12 Semibatch Denitration at $90^{\circ} \mathrm{C}$ and $2.5 \mathrm{cc}$ Formic Acid per Minute per Liter of Feed

\section{Induction Time}

In order to ensure that the reaction is initiated smoothly before significant amounts of formic acid have been added to the system, an upper operating limit on the formic acid addition rate and a lower operating limit on the pot temperature should be set. 
This ensures that the peak gas generation rate which occurs shortly after initiation can be accommodated within the maximum pressure limits of the system. (The pressure in the evaporator should be maintained at 7 inches of water or less for this system.)

The semibatch induction time was derived from the batch studies by assuming that the amount of autocatalytic agent necessary to initiate the reaction is constant. Assuming a constant volume and rapid mixing, the constant formic acid concentration term in Equation 6 is replaced by a linearly increasing formic acid concentration:

$$
\frac{\mathrm{d}(\mathrm{I})}{\mathrm{dt}}=\mathrm{k}_{1}\left[\mathrm{HNO}_{3}\right]\left(\frac{\mathrm{Mt}}{\mathrm{V}}\right) \exp \left(\frac{-27,800}{\mathrm{RT}}\right)
$$

where

$$
\begin{aligned}
& M=\text { formic acid addition rate, mol/min } \\
& V=1 \text { iquid volume, } \ell
\end{aligned}
$$

Equation 8 is integrated to obtain the relation between the semibatch induction time, $t^{\prime}$, and the critical concentration of autocatalytic agent (I)':

$$
(\mathrm{I})^{\prime}=\mathrm{k}_{1}\left[\mathrm{HNO}_{3}\right]\left(\frac{\mathrm{M}}{\mathrm{V}}\right) \exp \left[\frac{-27,800}{\mathrm{RT}}\right] \frac{\left(\mathrm{t}^{\prime}\right)^{2}}{2}
$$

If it is assumed that the critical concentration of autocatalytic agent necessary to initiate the reaction is a constant, then $(\mathrm{I})^{*}=(\mathrm{I})^{\prime}$, and Equations 7 and 9 can be set equal to one another. When the relation for $t$ * from Equation 5 is then substituted into Equation 7 , the semibatch induction time can be derived:

$$
\frac{1}{\mathrm{t}^{\top}}=3.5 \times 10^{8}\left[\frac{\mathrm{M}\left[\mathrm{HNO}_{3}\right]}{\mathrm{V}}\right]^{\frac{1}{2}} \exp (-13,900 / \mathrm{RT})
$$

The accumulated concentration of formic acid at the time the reaction initiates, $(\mathrm{HCOOH}) '$ is given by the product of the addition rate and the semibatch induction time:

$$
(\mathrm{HCOOH})^{\prime}=M t^{\prime}=2.9 \times 10^{-9}\left[\frac{\mathrm{M}}{\mathrm{V}\left[\mathrm{HNO}_{3}\right]}\right]^{\frac{1}{2}} \exp (13,900 / \mathrm{RT})
$$

Equation 10 predicts that at a fixed value of $\left[\frac{\mathrm{M}\left[\mathrm{HNO}_{3}\right]}{\mathrm{V}}\right]$ the reciprocal of the semibatch induction time will give an Arhennius plot with an effective activation energy of one-half the chemical activiation energy. Figure 13 shows that laboratory-scale semibatch data conform to this equation. 


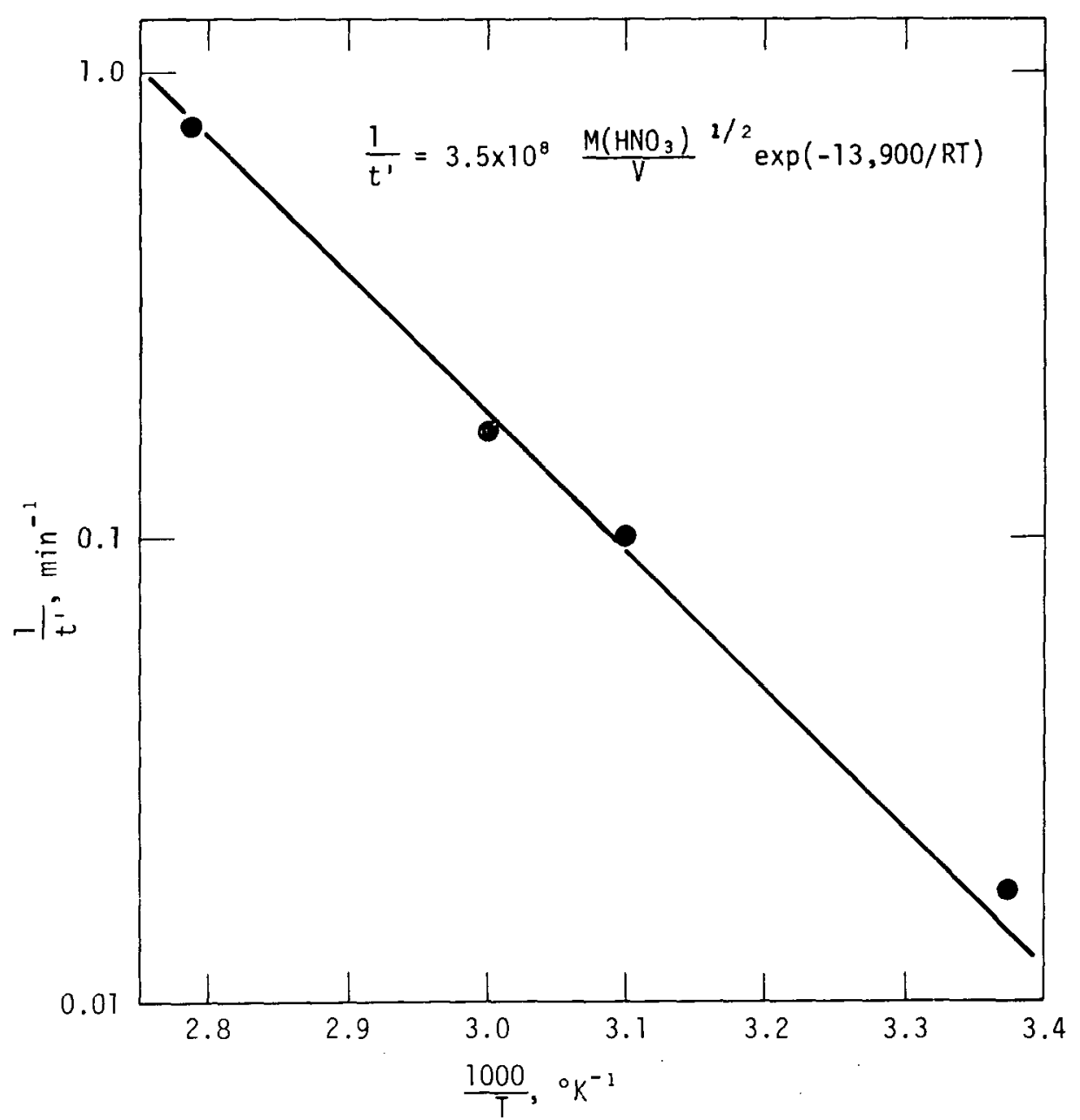

FIGURE 13 Induction Time in Semibatch Reactions

Equation 11 can be used to determine the maximum formic acid addition rates and minimum pot temperature to ensure a low concentration of formic acid at the beginning of the reaction. Based on the previous batch studies, the reaction should initiate with an accumulated formic acid concentration of $20.1 \mathrm{M}$ in order to minimize foaming and pressurization (Figures 10 and 11). Calculations using Equation 11 assuming $8 \mathrm{M} \mathrm{HNO}_{3}$ feed indicates that this can be accomplished by heating the pot to $\geqslant 90^{\circ} \mathrm{C}$ and limiting the formic acid addition rate to a maximum of $\sim 0.15 \mathrm{~mol} / \mathrm{min}$ per liter of nitric acid. An addition rate of $0.06 \mathrm{~mol} / \mathrm{min}$ per 1 iter of nitric acid was chosen as the addition rate for the semibatch tests to ensure a low accumulated concentration of formic acid when the reaction initiates. 
The induction times and accumulated formic acid concentrations calculated by these equations are maximum values in the sense that they are based on systems with no nitrous acid initially present. In actual plant solutions, some nitrous acid is expected to be present in the feed due to radiolytic decomposition of $\mathrm{HNO}_{3}$ and by reaction of $\mathrm{HNO}_{3}$ with trace amounts of organic solvents in the feed.

\section{Maximum Gas Evolution Rates}

In a semibatch denitration, the peak gas evolution rate occurs just after the reaction initiates. Peak gas evolution rates were measured for semibatch denitrations carried out at $90^{\circ} \mathrm{C}$ with a formic acid addition rate of $0.06 \mathrm{~mol} / \mathrm{min}$ per 1 iter of nitric acid (2.5 cc of $23.5 \mathrm{~m}$ Formic Acid per liter of $\mathrm{HNO}_{3}$ ) (Figure 14). The peak rate was approximately a linear function of the initial nitric acid concentration in the range investigated (up to $6 \mathrm{M} \mathrm{HNO}_{3}$ ).

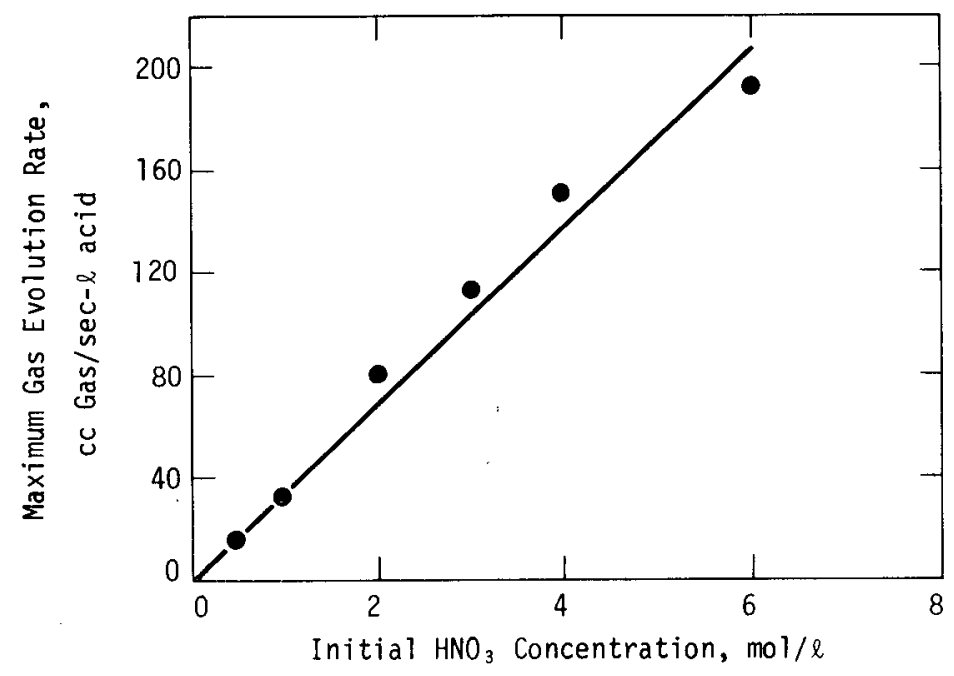

FIGURE 14 Maximum Gas Evolution Rates in Semibatch Reactions

\section{Mixing Effects}

The effect of mechanical agitation on the semibatch induction time was determined in a series of tests with and without mechanical agitation. The formic acid was added to $16 \mathrm{M} \mathrm{HNO}_{3}$ at $90^{\circ} \mathrm{C}$ at a rate of $2.5 \mathrm{cc} / \mathrm{min}$ per liter of feed. The semibatch induction times with agitation averaged $6 \pm 0.5$ minutes. In the absence of agitation the induction times were $3 \pm 2$ minutes.

The lack of agitation permits localized regions higher in formic 
acid concentration. Because the product of the nitric acid concentration and the formic acid concentration is higher in these regions than would be attained if the system were well mixed, the reaction initiates more rapidly, as predicted by Equation 5 . As soon as the reaction initiates, the autocatalytic agents spread rapidly to the remainder of the fluid. The bubbling action of the gaseous products that follow initiation is sufficient to keep the system well mixed for the remainder of the denitration.

In one test, the formic acid was added to the surface of the $16 \mathrm{M}$ nitric which was contained in a long cylinder to minimize mixing. The reaction was observed to initiate at the interface between the nitric acid and the formic acid within $30 \mathrm{sec}$. These effects are at a maximum in the $16 \mathrm{M} \mathrm{HNO}_{3}$ system where initiation times are at a minimum. Under these conditions, there is much less mixing due to natural convection before initiation.

Because mixing will be carried out in the equipment by air sparging, a study was made of the effect of bubbling air under the surface of the liquid using $4 \mathrm{M}$ and $8 \mathrm{M} \mathrm{HNO}_{3}$ feed. The air sparge increased the semibatch induction time (Figure 15). In addition to mechanical agitation effects, the air removes oxides of nitrogen and other volatile species in equilibrium with the autocatalytic agents that are being produced during the induction period. Therefore, air sparge mixing during the induction period is neither necessary nor desirable.

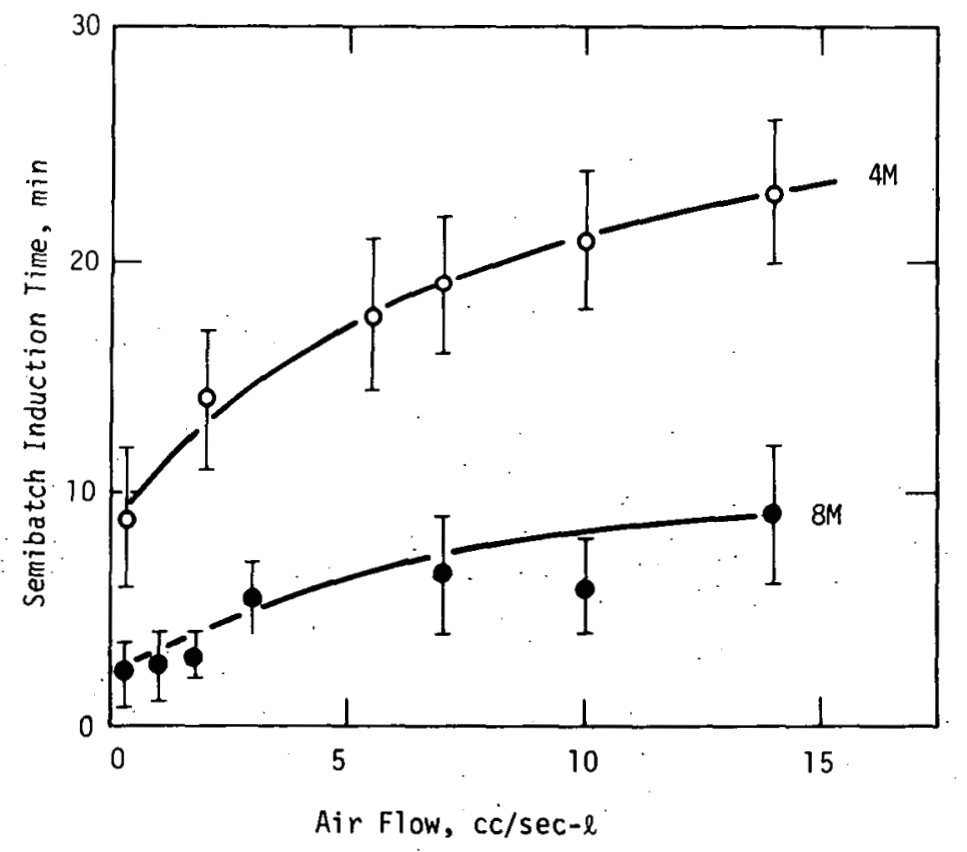

FIGURE 15 Effect of Air Sparge on Semibatch Induction Time 


\section{PLANT-SCALE STUDIES}

Plant-scale studies were carried out in an identical mockup of the plant evaporator and condenser to investigate the following parameters:

- Induction period and maximum gas evolution rates for batch and semibatch reactions

- Amount of formic acid to be added

- Effect of air sparge

- Effect of air purge

- Corrosion of evaporator and electric heaters

As in the laboratory studies, batch tests were run to study the kinetics of the system and to evaluate the consequences of suddenly adding large amounts of formic acid to the nitric acid. Semibatch tests were then made to determine the operating conditions of the process and operating characteristics of the equipment. All plant-scale tests were made with $10 \ell$ of nitric acid feed solution.

\section{Equipment}

A full-scale prototype evaporator including condenser, off-gas piping and seal pot relief piping were fabricated and tested. This equipment is shown in Figures 16, 17, and 18 and is identical to the plant unit except for minor changes necessary to allow for sampling of the evaporator solution while boiling and inspection of the equipment, and additional pressure relief piping on the pot for batch studies. Heat was supplied by two 6.5-kw electric heaters with a variable heat control.

\section{Batch Denitrations}

Tests were made to simulate worst case conditions where all safety devices failed. The entire stoichiometric volume of formic acid was added in less than $30 \mathrm{sec}$ to $10 \ell$ of various concentrations of $\mathrm{HNO}_{3}$. Two series of tests were run, one with the $\mathrm{HNO}_{3}$ at $40^{\circ} \mathrm{C}$ and one with the $\mathrm{HNO}_{3}$ at $90^{\circ} \mathrm{C}$. Results of these tests (Figure 19) show that the peak reaction pressure (an index of rate) increases exponentially with $\mathrm{HNO}_{3}$ concentration and is greater for $\mathrm{HNO}_{3}$ temperatures of $90^{\circ} \mathrm{C}$ than at $40^{\circ} \mathrm{C}$. These data show that the initial $\mathrm{HNO}_{3}$ concentration should not exceed $8 \mathrm{M}$ to ensure against pressures that could release contamination to a clean area. The peak pressure rise was correlated by an empirical equation and found to be proportional to $\exp (1.02) \quad\left[\mathrm{HNO}_{3}\right]$ at pressure $<7$ inches (the pressure at which the condenser seal relieves) and $\exp (0.831)\left[\mathrm{HNO}_{3}\right]$ at pot pressures $>7$ inches. 


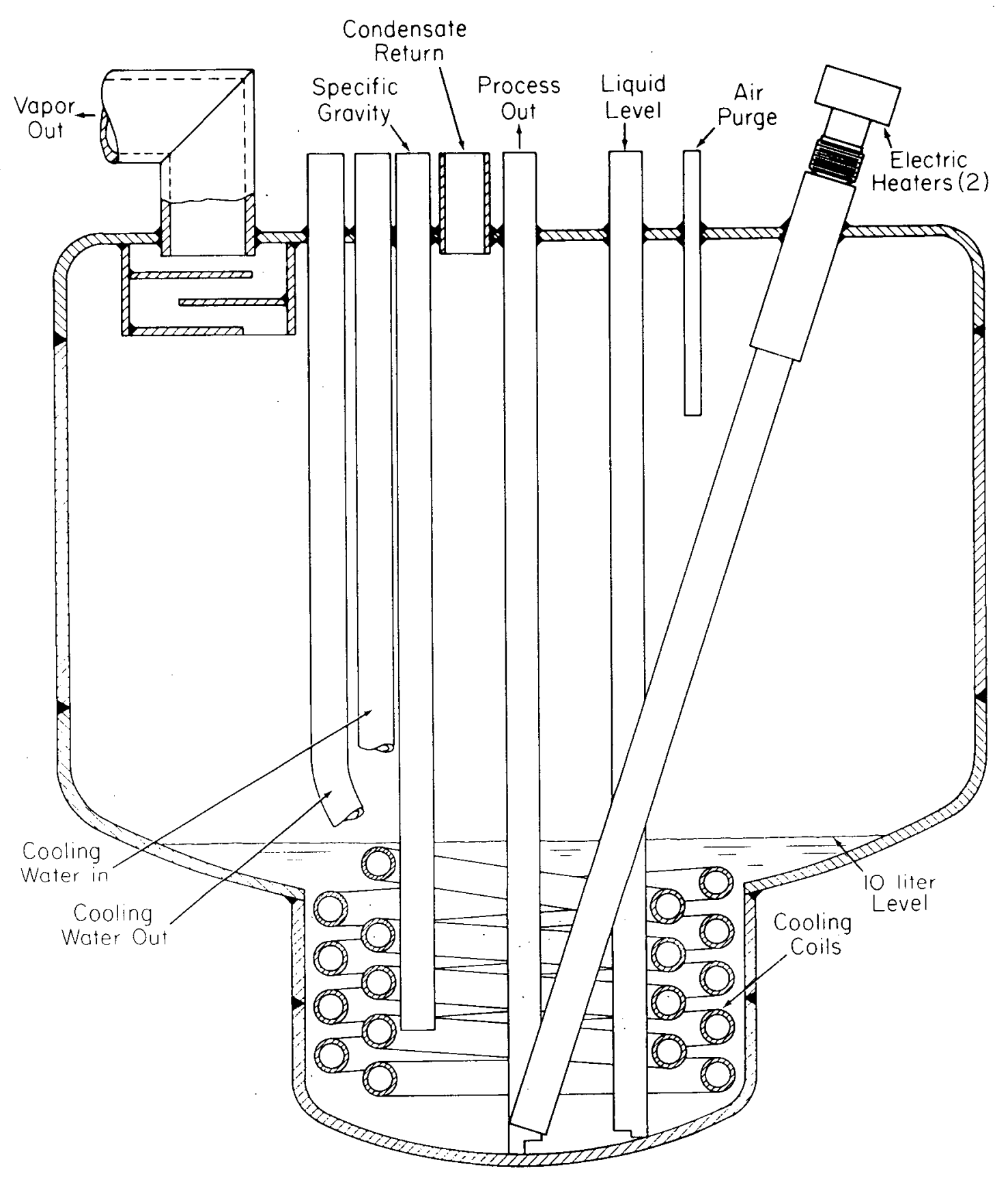

FIGURE 16 Plant-Scale Denitration Evaporator Pot 


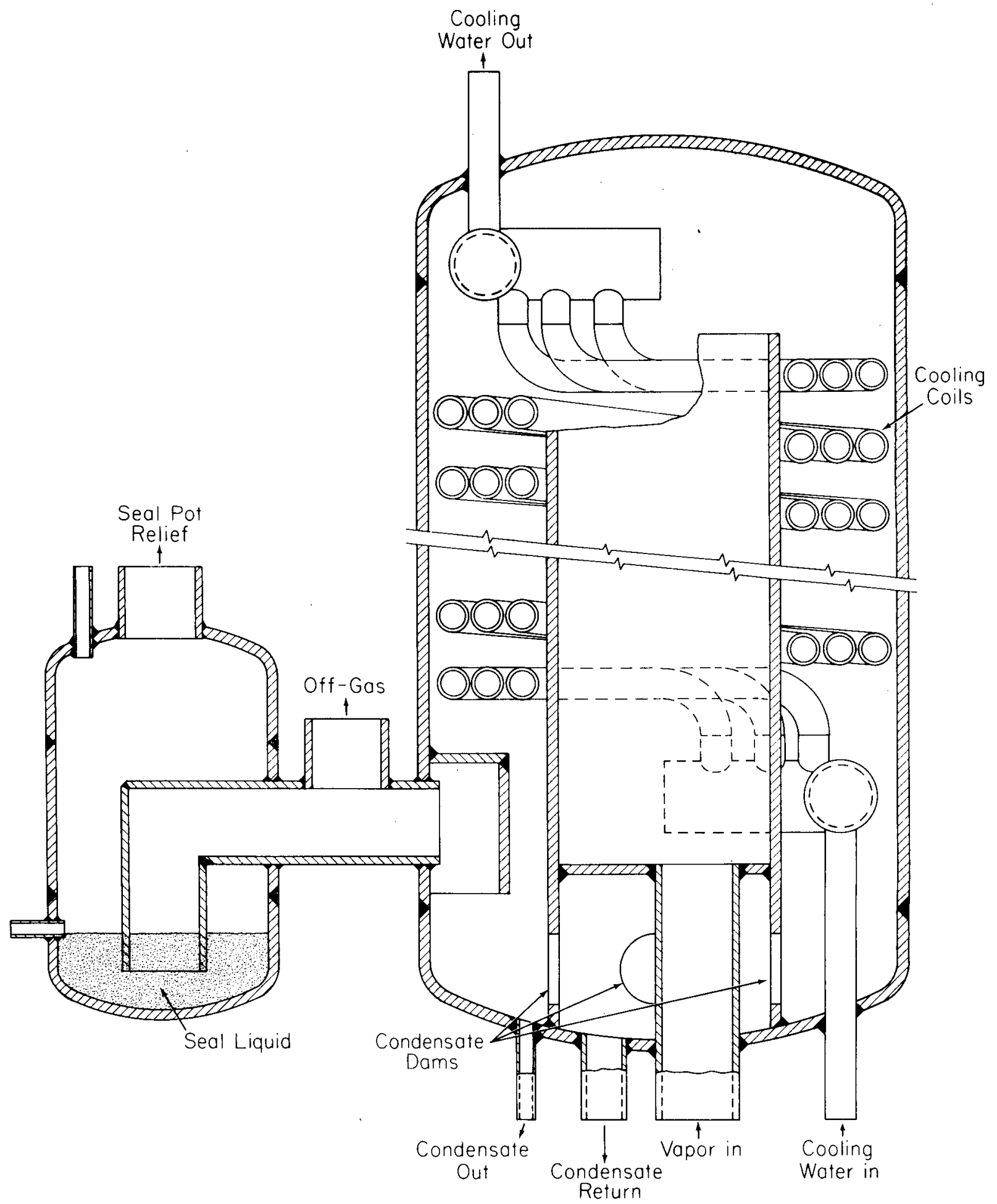

FIGURE 17 Plant-Scale Denitration Condenser 


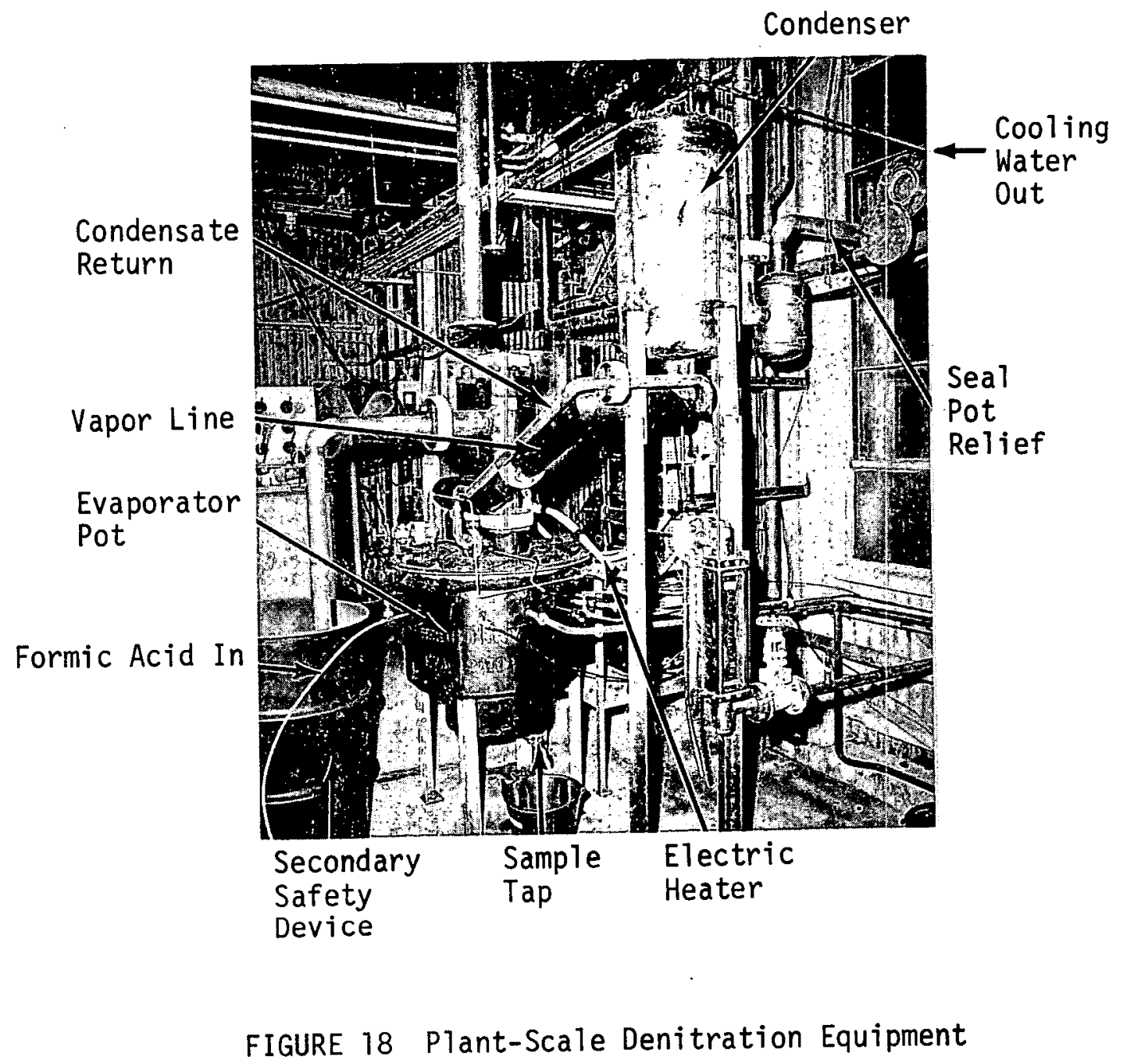




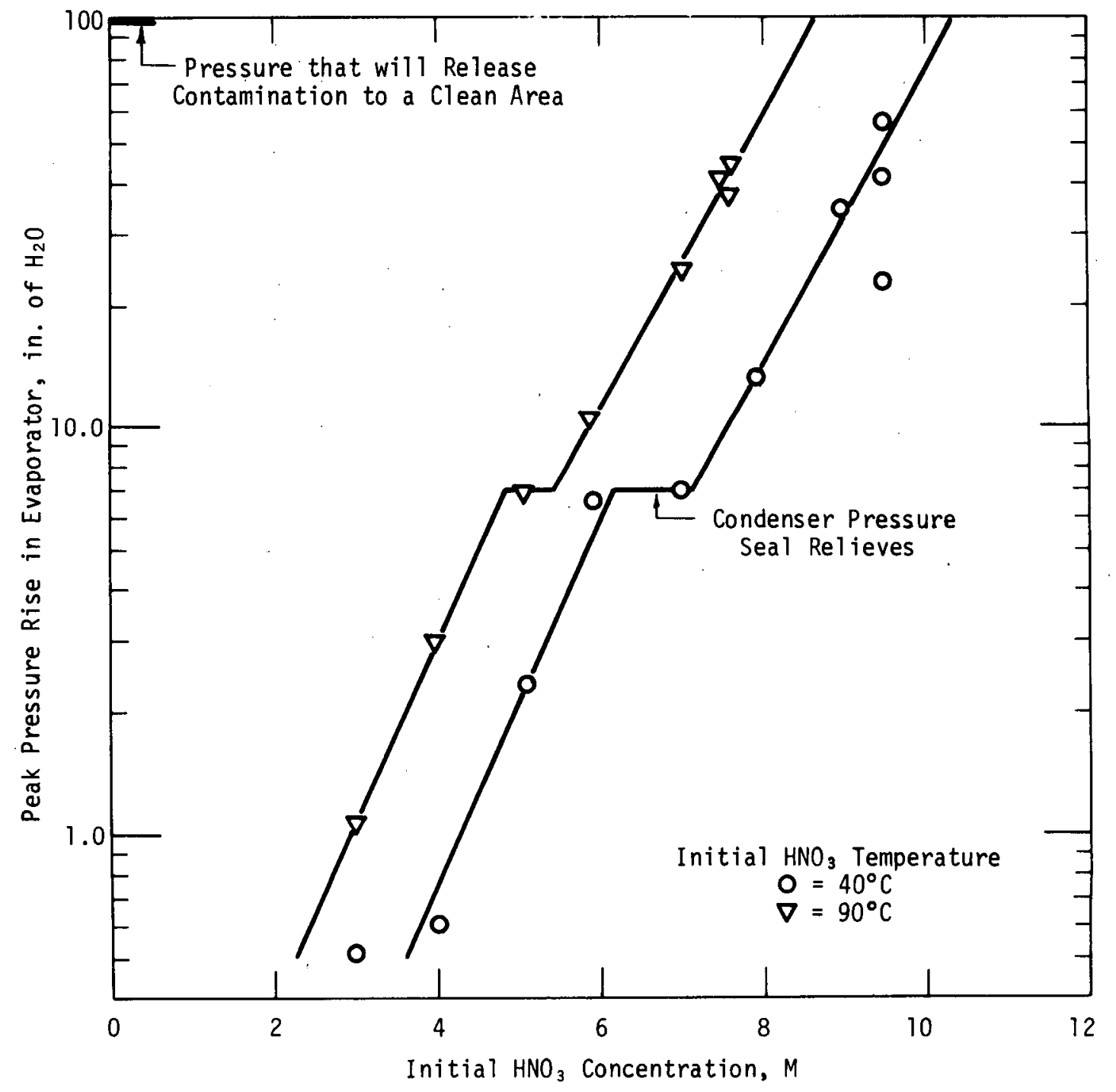

FIGURE 19 Effect of Initial $\mathrm{HNO}_{3}$ Concentration on Peak Pressure Rise in Plant-Scale Batch Reactions 
Based on air flow calibration of the equipment, peak off-gas flow rates were estimated from the peak pressures given in

Figure 19. These estimates show that the peak off-gas flow rate is a strong function of $\mathrm{HNO}_{3}$ concentration (Figure 20): the molecular weight of the off-gas was assumed to be 45 . The peak off-gas rates measured in the laboratory tests are also shown in Figure 20 normalized to a $10-\ell$ volume.

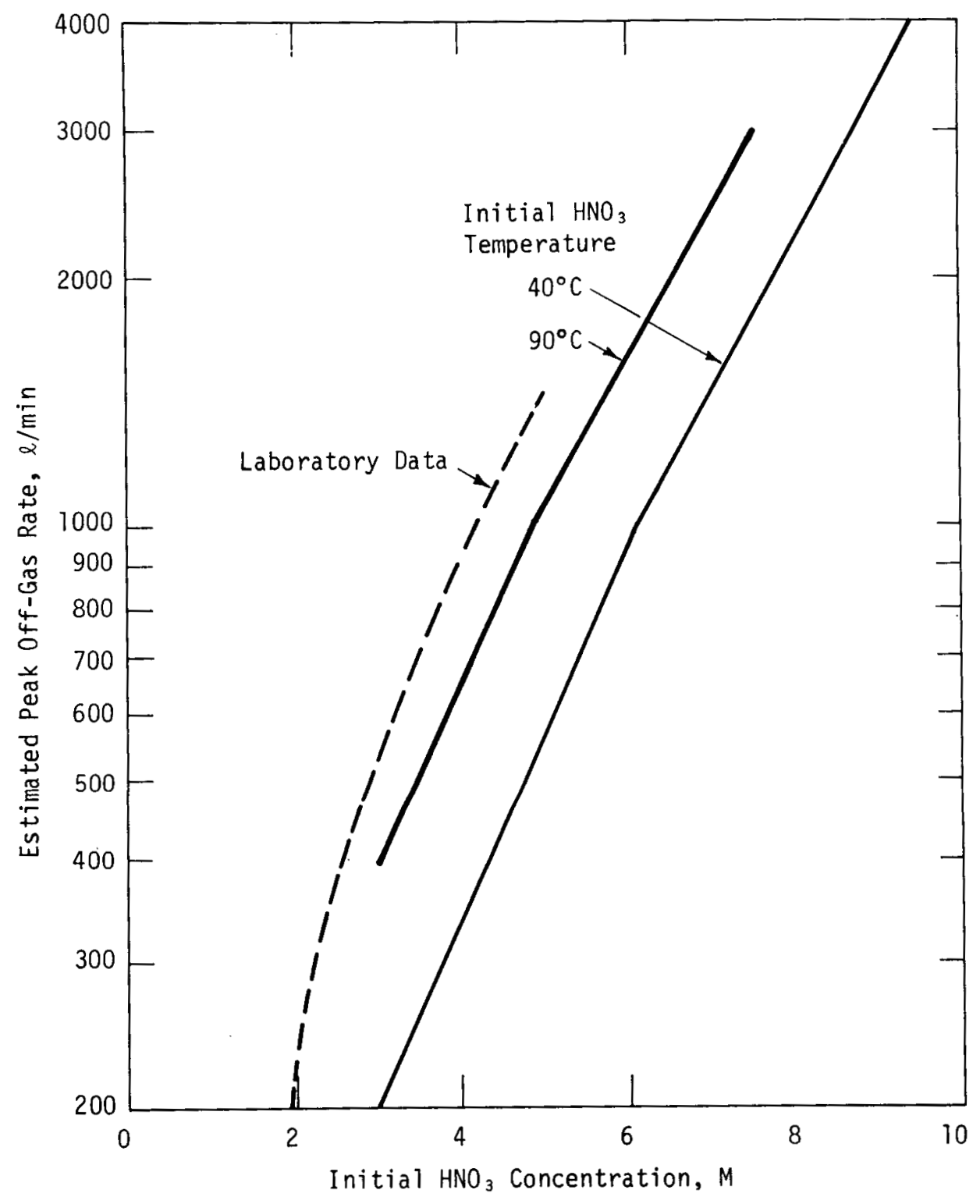

FIGURE 20 Estimated Peak Off-Gas Evolution Rate in Plant-Scale Batch Reactions 
A series of tests were made to determine the effect of the volume of formic acid added to $\mathrm{HNO}_{3}$. For these tests $1 / 4,1 / 2$, $3 / 4$, and all of the stoichiometric volume of $23.5 \mathrm{M}$ formic acid was added rapidly (less than $20 \mathrm{sec}$ ) to 10 \& $7.5 \mathrm{M} \mathrm{HNO}$ at $90^{\circ} \mathrm{C}$. These tests (Figure 21) showed that the peak reaction pressure increased exponentially with increasing quantities of formic acid until the quantity was equal to $3 / 4$ of the stoichiometric amount when the pressure began to level out.

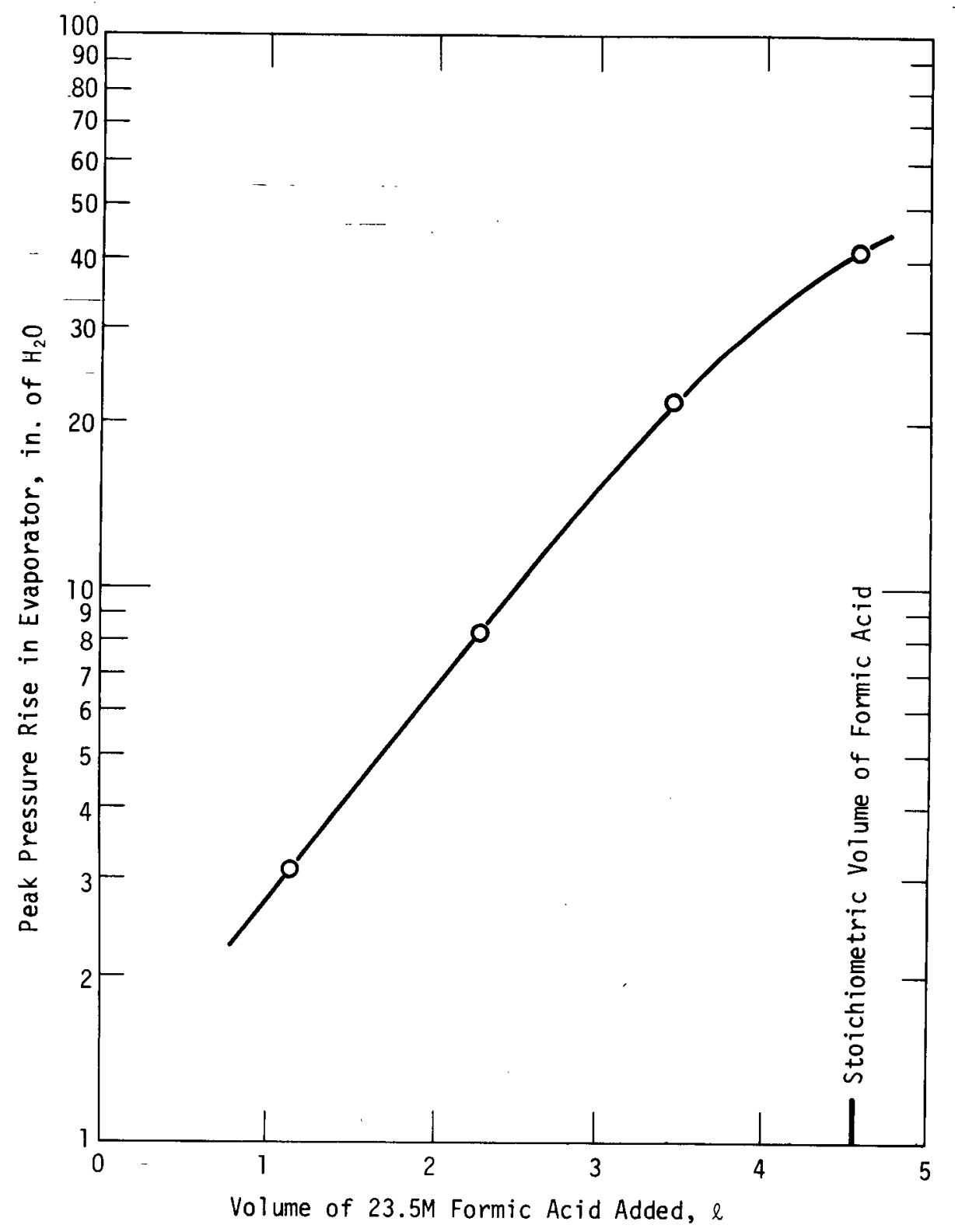

FIGURE 21 Effect of Volume of Formic Acid Added on Peak Pressure Rise in Plant-Scale Evaporator 


\section{Semibatch Denitrations}

\section{Typical plant Tests}

The full-scale plant evaporator and condenser were tested by carrying out full-scale denitrations at initial $\mathrm{HNO}_{3}$ concentrations of $4 \mathrm{M}$ through $15.6 \mathrm{M} \mathrm{HNO}$. A typical test is shown in Figure 22. The acid solution was heated to $93^{\circ} \mathrm{C}$ and addition of formic acid was started at $\sim 25 \mathrm{ml} / \mathrm{min}$. Six minutes later, initiation of the reaction is indicated by the sharp 0.3 -inch rise in pot pressure, lasting less than 1 minute. The solution specific gravity (and hence indicated water height in evaporator) decreased during heating and reaction; volume in the evaporator is constant. Concentrations of $\mathrm{H}^{+}$and $\mathrm{HNO}_{3}$ begin to decrease as the reaction begins and are equal above $2 \mathrm{M} \mathrm{HNO}_{3}$; this demonstrates very rapid reaction of formic acid. As the $\mathrm{HNO}_{3}$ concentration decreases to $\sim 2 \mathrm{M}$, total acidity does not decrease as rapidly as $\mathrm{HNO}_{3}$ concentration; this indicates buildup of formic acid due to slower reaction. During the 2-hour refluxing period, formic acid and $\mathrm{HNO}_{3}$ continue to react although at a slower rate. Final $\mathrm{H}^{+}$concentration was $<1.3 \mathrm{M} ; \mathrm{HNO}_{3}$ concentration was $<0.8 \mathrm{M}$.

The optimum reactant ratio obtained in the plant-scale evaporator with an air purge of $0.05 \mathrm{scfm}$ (the minimum for the liquid level and specific gravity bubblers) was found to be similar to that obtained in laboratory tests (Figure 23).

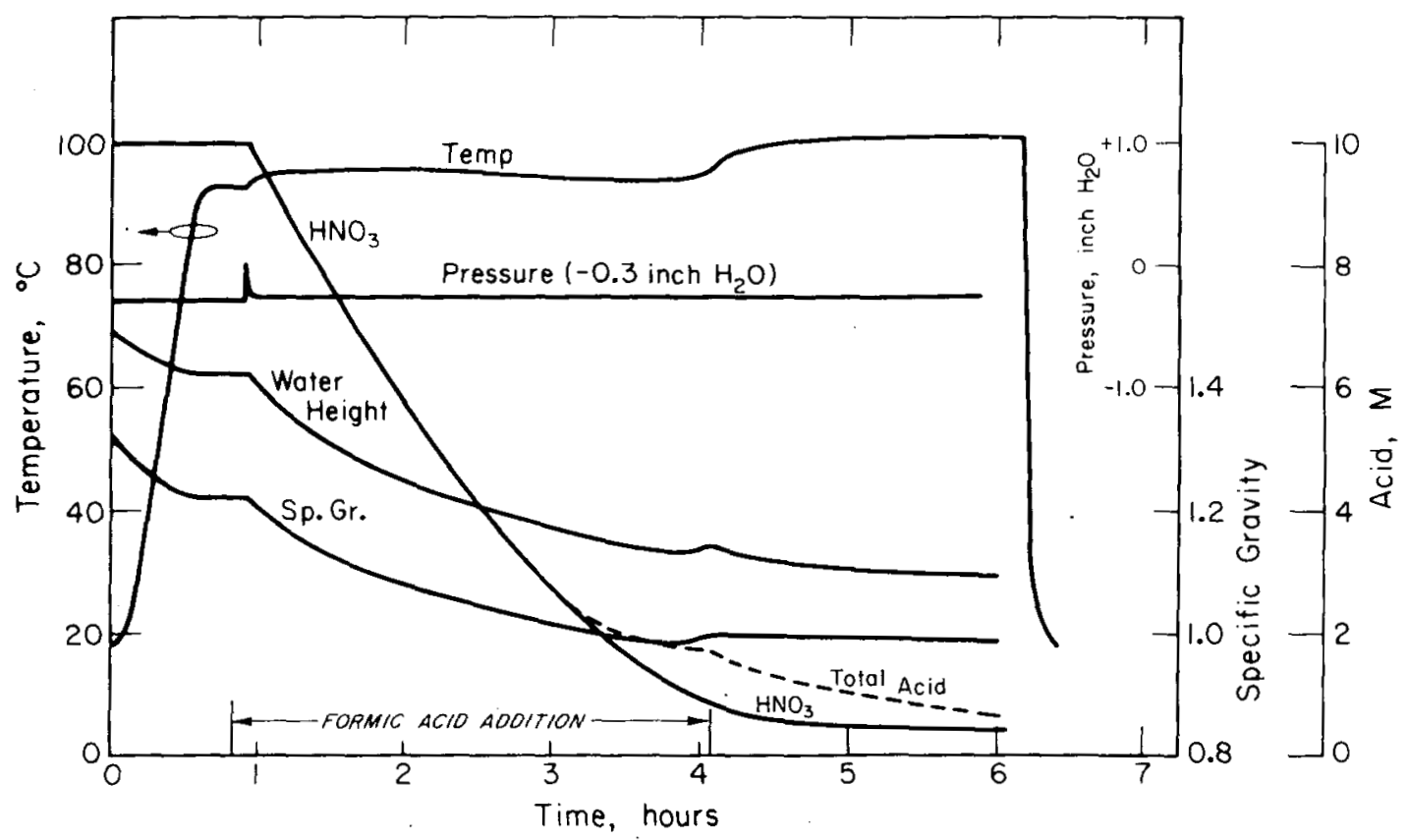

FIGURE 22 Piant-Scale Denitration with Formic Acid 


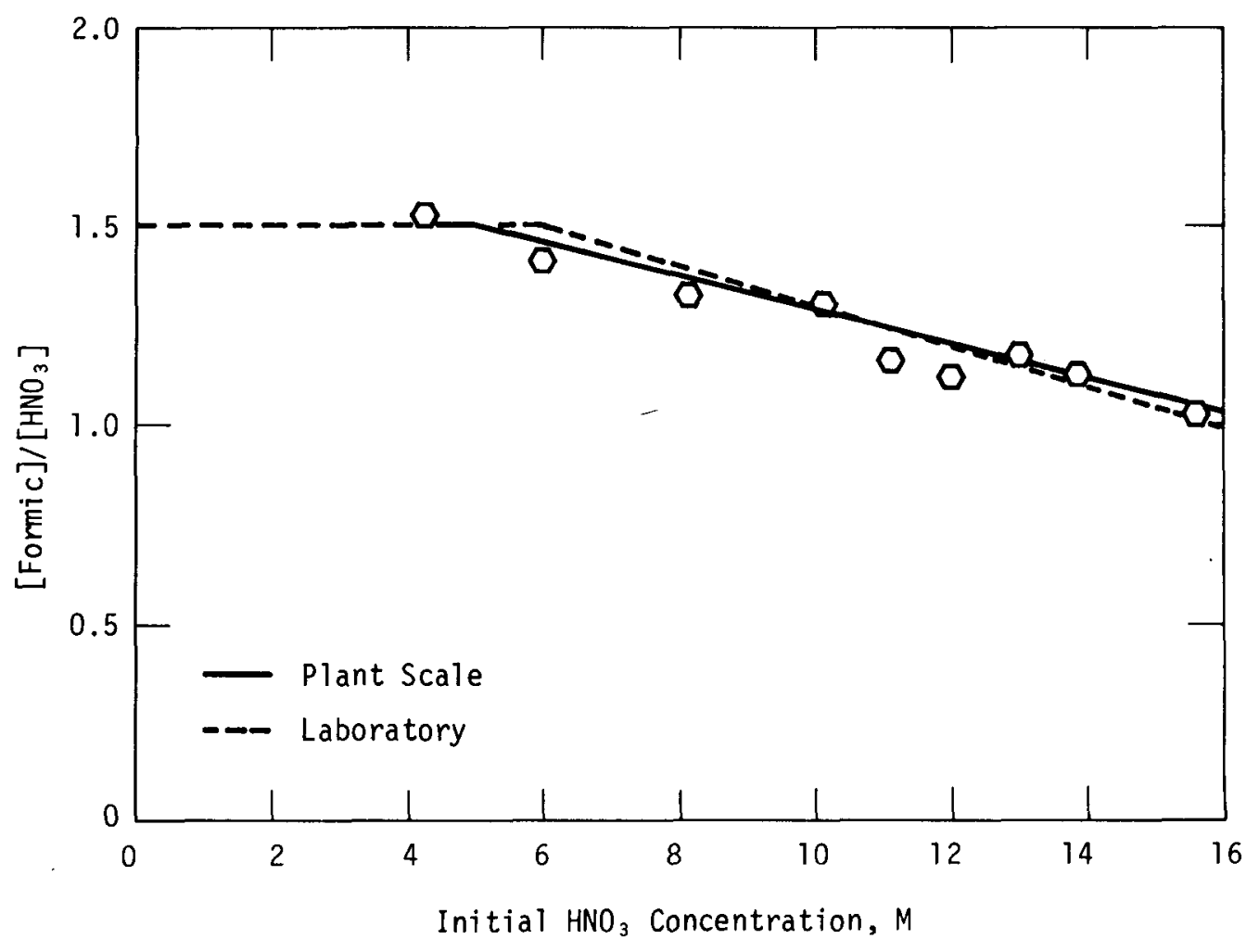

FIGURE 23 Optimum Formic Acid/Nitric Acid Addition Ratio

\section{Effect of Air Purge}

When feed solutions contain high levels of radioactivity, an air purge must be added to the vessel to maintain the concentration of radiolytically produced hydrogen below the lower flammable limit. As much as 1 scfm of air purge may be required for some of the feeds expected for ion exchange processing in this system. Additional tests were made at air purge rates up to $3 \mathrm{scfm}$ in the plant-scale equipment. The air purge was added to the vapor space of the evaporator. Tests were carried out at an initial acidity of $\sim 4 \mathrm{M} \mathrm{HNO}_{3}$ at the expected formic acid addition rate of $225 \mathrm{ml} / \mathrm{min}$. The condenser temperature was varied from 26 to $48^{\circ} \mathrm{C}$.

The results of these tests showed that the formic acid consumption ratio began to exceed the stoichiometric ratio of 1.5 mol formic per mol of nitric at air purge rates above 0.3 scfm (Table III). This effect is attributed to loss of formic acid from the system by evaporation at the higher air flow rates. At the higher air flow rates the consumption ratio was as high as 2.5 mol formic per mol of nitric. The data could not be correlated in this range with the variables tested. These tests indicate 


\section{TABLE III}

Effect of Air Purge Rate and Condenser Temperature on Formic Acid/Nitric Acid Ratio

(Semicontinuous denitration with formic acid added to $4 \mathrm{M} \mathrm{HNO}_{3}$ at $93^{\circ} \mathrm{C}$ followed by a $2-\mathrm{hr}$ boiling period)

$\begin{array}{lcc}\begin{array}{c}\text { Air } \begin{array}{c}\text { Purge Rate, } \\ \text { scfm }\end{array} \\$\cline { 1 - 2 } 0.02\end{array} & $\begin{array}{c}\text { Condenser Temperature, } \\ { }^{\circ} \mathrm{C}\end{array} & \begin{array}{c}\text { Formic/HNO } \\ \text { Ratio }\end{array} \\ 0.05 & 34 & 1.48 \\ 0.33 & 17 & 1.54 \\ 0.33 & 35 & 1.42 \\ 0.5 & 30 & 1.82 \\ 0.5 & 35 & 1.45 \\ 0.5 & 32 & 1.83 \\ 0.67 & 36 & 1.92 \\ 0.83 & 28 & 2.04 \\ 1.0 & 30 & 1.85 \\ 1.0 & 37 & 1.94 \\ 1.0 & 48 & 1.80 \\ 1.0 & 24 & 1.90 \\ 1.0 & 26 & 2.33 \\ 1.0 & 36 & 2.19 \\ 1.0 & 36 & 2.20 \\ 1.0 & 48 & 2.17 \\ 1.26 & 26 & 2.46 \\ 2 & 35 & 1.87 \\ 3 & 35 & 1.85 \\ & 34 & 1.74\end{array}$


that if high air purge rates are necessary during the denitration reaction, a second denitration may be required in some cases.*

In several of the tests, rare earths were added to the feed solutions at $0.25 \mathrm{M}$ to simulate the presence of these cations in ion exchange feed solutions. The presence of the rare earths at this concentration level had no effect upon the denitration.

\section{Formic Acid Addition Rate}

Tests were made at formic acid addition rates of $1,2,3$, and 4 times the normal plant rate. Figure 24 shows that peak reaction pressure (an index of reaction rate) is only 1.5 inches of water at an addition rate of $100 \mathrm{ml} / \mathrm{min}$ to $8 \mathrm{M} \mathrm{HNO}_{3}$. (At an evaporator pressure of $\sim 7$ inches of water, the safety seal on the condenser will exhaust vapor into the plant canyon but not to personnel areas.)

Equation 10, derived previously from a theoretical analysis of the laboratory data, predicts that the semibatch induction time is proportional to the quantity

$$
\sqrt{\frac{\mathrm{V}}{(\mathrm{M})} \frac{\mathrm{HNO}}{\left[\mathrm{HNO}_{3}\right]}}
$$

where

$$
\begin{aligned}
(\mathrm{M}) & =\text { formic acid addition rate, } \mathrm{mol} / \mathrm{min} \\
{\left[\mathrm{HNO}_{3}\right] } & =\mathrm{HNO}_{3} \text { concentration, mol/ } \ell \\
\mathrm{V} & =1 \text { iquid volume, } \ell
\end{aligned}
$$

The semibatch induction times given in Figure 24 for the plant-scale tests follow the same correlation with respect to $\mathrm{HNO}_{3}$ concentration and formic acid addition rate (Figure 25). However the plant-scale induction times were greater than predicted from Equation 10 alone due to the presence of a 0.05 scfm air sparge from the liquid level and specific gravity bubblers in the plant-scale equipment. At this air sparge rate ( $2.5 \mathrm{cc}$ of air per second per 1iter of solution) the effect on induction time is significant as demonstrated in laboratory tests (Figure 15).

* For most of these tests at the higher air flow rates the final acidity of the product would have been acceptable for ion exchange processing. 


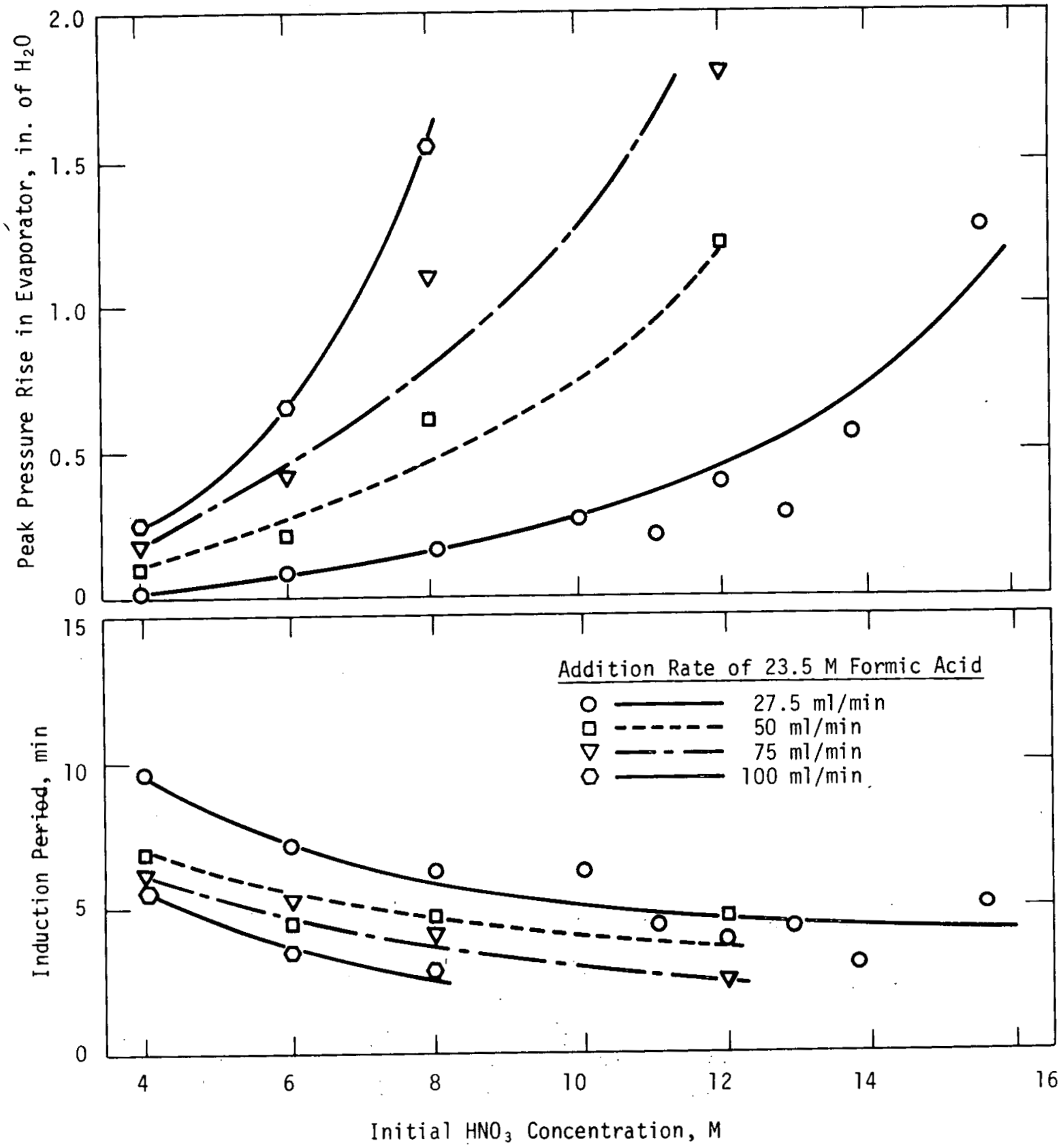

FIGURE 24 Effect of Formic Acid Feed Rate on Peak Pressure Rises and Induction Time in Plant-Scale Evaporator 


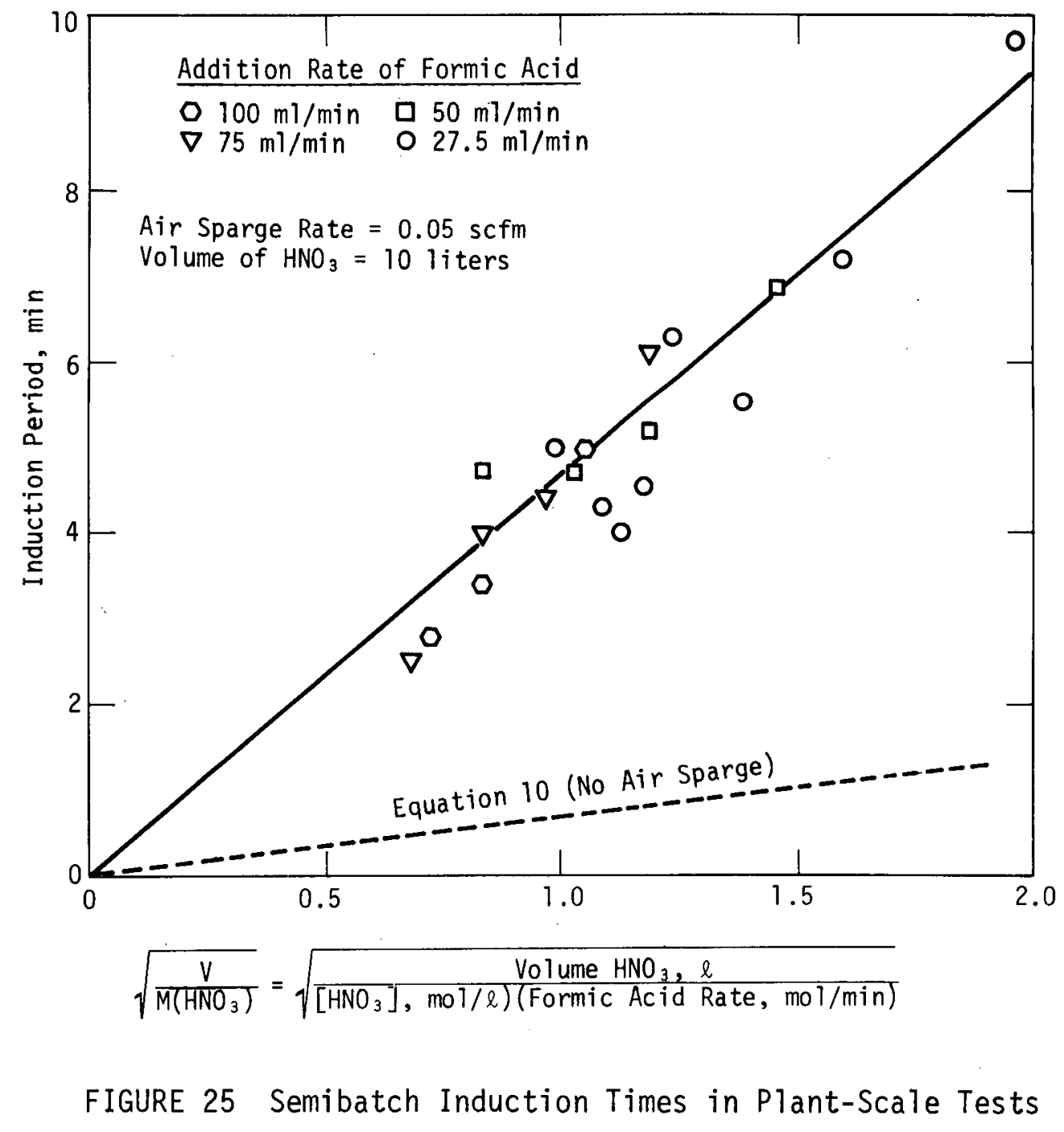


Peak off-gas evolution rates were calculated from the peak pressure measurements for the expected formic acid addition rate (Figure 26). These data are in good agreement with laboratory data taken at the same relative formic acid addition i rate (the laboratory data are normalized to the 10-1iter volume).

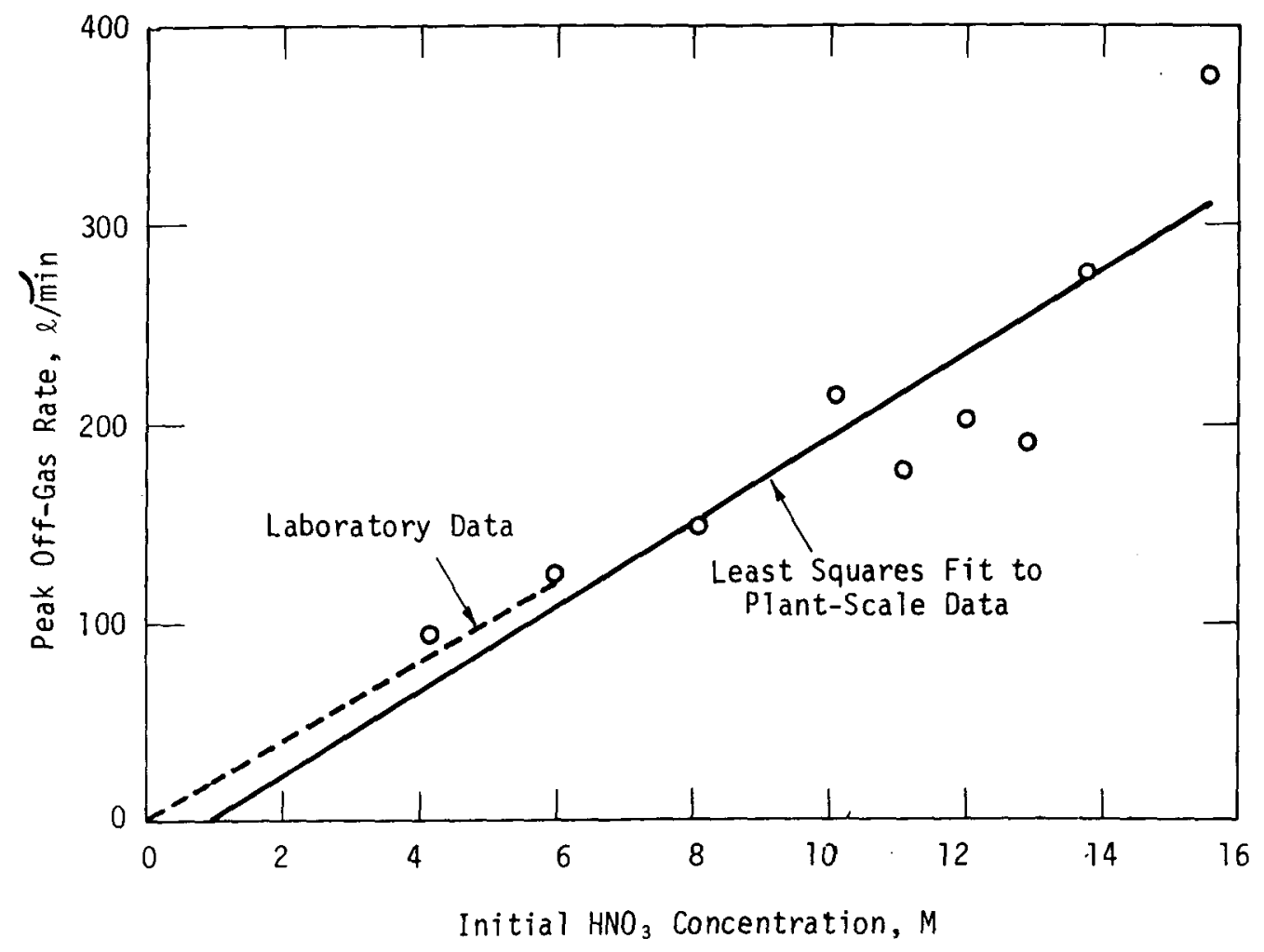

FIGURE 26 Peak Off-Gas Rate

Effect of Air Sporge

The effect of a large air sparge was determined for a plantscale semibatch denitration with $10 \mathrm{M} \mathrm{HNO}_{3}$ feed. The air sparge rate for this test was $0.67 \mathrm{scfm}$ of air. (A standard rate of 0.05 scfm was used for al1 other tests.) As in the laboratory tests, the induction time was significantly greater at the higher air sparge rate: $15 \mathrm{~min}$ at $0.67 \mathrm{scfm}$ vs $6 \mathrm{~min}$ at $0.05 \mathrm{scfm}$. The peak pressure rise was also significantly greater: 1.3 inches of water at $0.67 \mathrm{scfm} v \mathrm{~s} 0.2$ inches of water at $0.05 \mathrm{scfm}$. This test emphasizes the importance of minimizing the air sparge rate during the semibatch induction period. 


\section{Corrosion}

The plant-scale evaporator was used for corrosion testing. During the test period, 71 denitrations (435 hours exposure) were made. Also a special corrosion test of the electrical heaters was made where $11 \mathrm{M} \mathrm{HNO}_{3}$ was boiled for 115 hours at a power input of $3 \mathrm{kw}$ to each of the two heaters.

A11 evaporator components were in excellent condition (Figure 27). Calculated corrosion rates for corrosion coupons present in the evaporator were as follows:

- Sensitized A1S1 Type 316L stainless steel: 0.001 to 0.003 inches/month (6 samples)

- Sensitized A1S1 Type 304L stainless steel: less than 0.001 inch/month (6 samples)

Visual inspection of the $304 \mathrm{~L}$ cladding on the electrical heaters showed them to be in excellent shape. No general or pitting corrosion was noted.

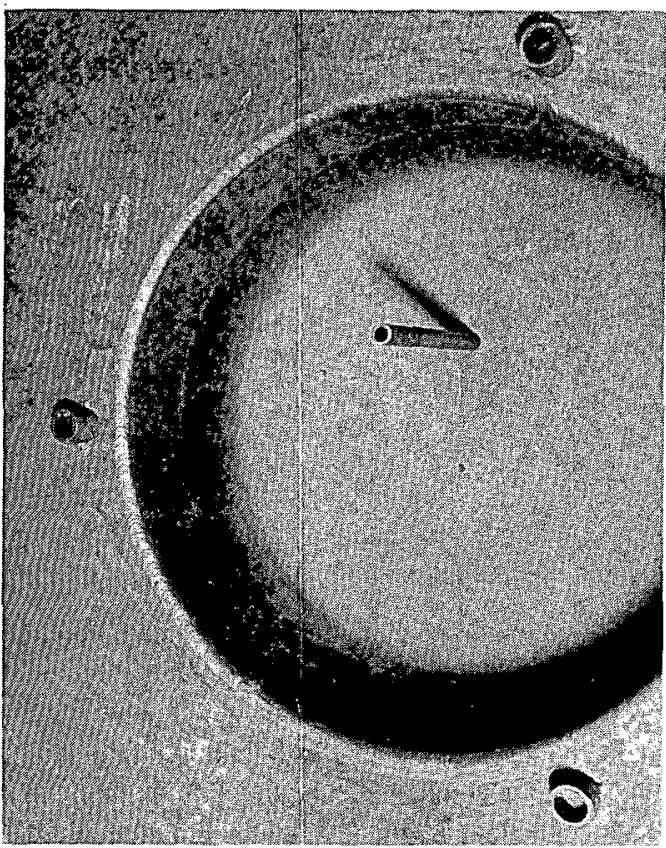

Bottom of Evaporator Pot

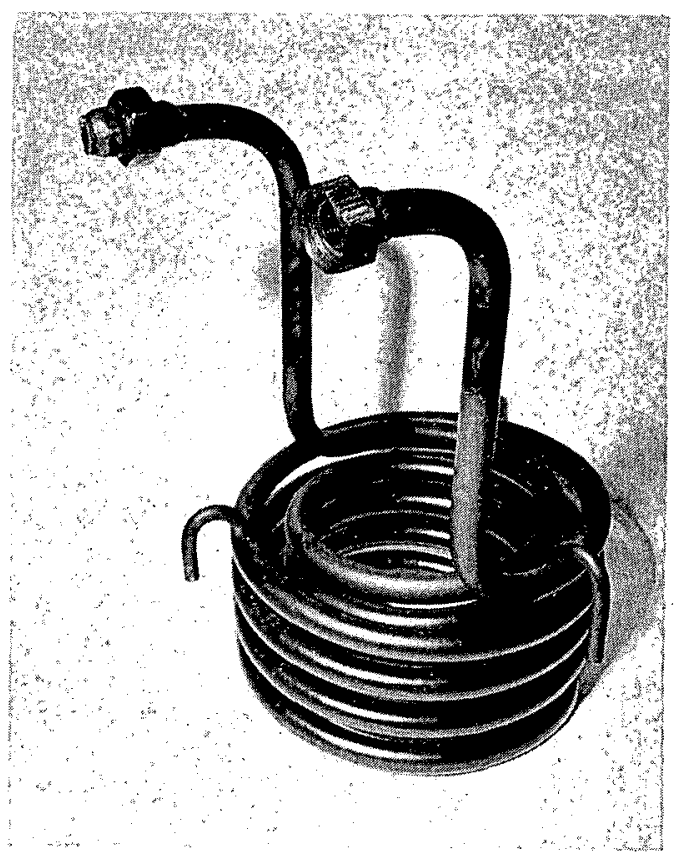

Cooling Coil

FIGURE 27 Plant-Scale Evaporator at Conclusion of Tests 


\section{REFERENCES}

1. J. T. Lowe, W. H. Hale, and D. F. Hallman. "Development of a Pressurized Cation Exchange Chromatographic Process for Separation of Transplutonium Actinides." Ind. Eng. Pro. Design Devel. 10 (1) 131-135, 1971.

2. L. A. Bray. Denitration of Purex Wastes with Sugar. USAEC Report HW-76973 REV, Hanford Atomic Products Operation, Richland, Washington (1963).

3. R. C. Forsman and G. C. Oberg. Formaldehyde Treatment of Purex Radioactive Wastes. USAEC Report HW-79622, Hanford Atomic Products Operation, Richland, Washington (1963).

4. W. H. Adams, E. B. Fowler, and C. W. Christenson. "A Method for Treating Radioactive Nitric Acid Wastes Using Paraformaldehyde." Ind, Eng. Chem. 52 (1) 55 (1960).

5. T. V. Healy. "The Reaction of Nitric Acid with Formaldehyde and with Formic Acid and Its Application to the Removal of Nitric Acid from Mixtures." J. App 2. Chem. 8, 553 (1958).

6. J. V. Longstaff and K. Singer. "The Kinetics of Oxidation by Nitrous Acid and Nitric Acid. Part II. Oxidation of Formic Acid in Aqueous Nitric Acid." J. Chem. Soc. 1954, 2610 (1954).

7. J. W. Wright and G. O. Nelson. The Production of Polonium. USAEC Report TID-5316, Mound Laboratory, Miamisburg, Ohio (1955). 